\title{
Viðhorf Íslendinga til innflytjenda á Íslandi
}

\section{Eva Heiða Önnudóttir}

\begin{abstract}
Ágrip: Í pessari grein er fjallað um niðurstöður úr könnun Rannsóknarmiðstöðvar Háskólans á Bifröst par sem íslenskir ríkisborgarar voru spurðir út í viðhorf peirra til innflytjenda á Íslandi. Svörin voru borin saman við fyrirliggjandi gögn úr sambærilegum könnunum á Íslandi og í öðrum Evrópuríkjum. Byrjað er á pví að fjalla stuttlega um fjölgun innflytjenda á Íslandi síðustu ár og um próun í átt að fjölmenningarsamfélagi. Rannsókninni var meðal annars ætlað að kanna hvort peir sem eru félagslega og efnahagslega verr staddir en aðrir hafi neikvæðari afstöðu til innflytjenda samanborið við pá sem hafa betri félagslega og efnahagslega stöðu og benda niðurstöður til pess að svo sé. Peirri spurningu er velt upp hvort pað geti verið vegna pess að peir sem eru verr staddir upplifi innflytjendur frekar sem samkeppnisaðila á vinnumarkaði. Af rannsókninni má draga pá ályktun að Íslendingar hafi almennt jákvæðari afstöðu til innflytjenda en aðrar pjóðir prátt fyrir að peir hafi orðið neikvæðari í peirra garð á síðustu árum samhliða pví sem innflytjendum hefur fjölgað á Íslandi.
\end{abstract}

Lykilorð: innflytjendur; viðhorf til innflytjenda; fjölmenning; aðlögun; Ísland

\begin{abstract}
This article reports on the results of a survey by the Bifröst University Research Center in which Icelandic citizens were asked about their views on immigrants in Iceland. The answers were compared with existing data from similar surveys in Iceland and other European countries. The article begins with a brief discussion of the increased number of immigrants in Iceland in the past few years and Iceland's development towards a multicultural society. Among the goals of the survey was to see whether those who are socioeconomically worse off have a more negative view of immigrants than those who are in a better socioeconomic position, and the results suggest that this is indeed the case. The article considers whether this might be because those who are worse off experience immigrants as competition on the labor market. The survey shows that Icelanders in general have a more positive view of immigrants than in other countries, even though this view has become more negative in recent years at the same time as the number of immigrants in Iceland has increased.
\end{abstract}

Keywords: immigration; views of immigrants; multiculturalism; integration; Iceland

\section{Inngangur}

Á síðustu áratugum hafa fólksflutningar á milli landa færst í aukana og hefur Ísland ekki farið varhluta af pví (Unnur Dís Skaptadóttir, 2004). Ýmsar ástæður geta legið að baki pessum fólksflutningum, allt frá átökum í heimalöndum innflytjenda yfir í leit að betri lífskjörum. Á Íslandi hefur innflytjendum fjölgað verulega frá síðustu aldamótum (Hagstofa Íslands, 2009a) en lítið verið gert af pví að rannsaka aðbúnað og 
upplifun innflytjenda sem og viðhorfum Íslendinga (innfæddra) til innflytjenda og er pessari grein ætlað að vera innlegg í fræðilega jafnt sem opinbera umræðu um innflytjendur á Íslandi.

Fólksflutningum innan og til og frá Evrópu frá miðri 19. öld fram á níunda áratug síðustu aldar má skipta í fjögur tímabil (Rystad, 1992). Fyrsta tímabilið sem náði fram að fyrri heimsstyrjöldinni einkenndist af frjálsum fólksflutningum, bæði innan Evrópu og frá Evrópu til annarra heimsálfa. Fólki var frjálst að flytja nær hvert sem er og purfti pað ekki að sækja sérstaklega um atvinnuleyfi í peim ríkjum sem pað flutti til. Annað tímabilið, sem hófst við upphaf fyrri heimsstyrjaldarinnar og stóð til loka peirrar seinni, einkenndist af pví að ríkisstjórnir hófu að reyna að stýra flæði innflytjenda með pví að setja lög og reglur um fólksflutninga og höft á pað hverjir gætu sest að og starfað innan marka ríkisins. Á priðja tímabilinu, sem stóð frá lokum seinni heimsstyrjaldar fram til byrjun áttunda áratugarins, var höftum aflétt í flestum vestrænum ríkjum á pví hverjir gætu flutt til og starfað innan ríkjanna. Рað var meðal annars gert vegna pess að ríkin purftu á ódýru vinnuafli að halda. Eftir miðjan áttunda áratuginn og fram til 1980 tók við fjórða tímabilið sem einkenndist af mikilli stjórnun og höftum á hverjir gætu flutt á milli landa eða svæða og átti pað sérstaklega við um lönd sem ekki höfðu gert með sér sérstakt samkomulag um frjálsa för fólks. Ef einungis er litið til Norðurlandanna pá gerðu pau með sér samkomulag um frjálsa för launafólks, árið 1954. Eftir stækkun Evrópska efnahagssvæðisins (EES) árið 2004, sem öll Norðurlöndin voru pá og eru enn aðilar að, jókst fjöldi innflytjenda til Norðurlandanna verulega (Dølvik og Eldring, 2008). Aðild að EES samningnum felur meðal annars í sér frjálsa för launafólks innan aðildarríkja Fríverslunarsamtaka Evrópu (EFTA) og Evrópusambandsins (ESB). Pegar við bættust tíu ný aðildarríki í ESB árið 2004 fjölgaði bæði peim innflytjendum sem komu til Norðurlandanna til skamms tíma vegna vinnu og peim sem komu til að setjast að, sér í lagi í Noregi og á Íslandi (Dølvik og Eldring, 2008).

Á Íslandi voru erlendir ríkisborgarar innan við 2\% landsmanna frá pví um miðja 20. öld fram undir miðjan 10. áratuginn. Á árunum 1996 til 2006 fjölgaði erlendum ríkisborgurum úr 1,8\% í 4,6\% og árið 2008 voru peir 6,8\% landsmanna (Hagstofa Íslands, 2009b). Á pessu tímabili, framundir haustið 2008, var næg atvinna á Íslandi og margir erlendir ríkisborgarar fengu störf innan byggingariðnaðarins og við stóriðju- og virkjanaframkvæmdir. Á sama tíma jókst atvinnupátttaka erlendra ríkisborgara hér á landi úr 5,5\% árið 2005 í um 9\% árið 2007 (Vinnumálastofnun, 2007). Á mynd 1 má sjá tölur yfir erlendra aðfluttra og brottfluttra ríkisborgara á Íslandi frá árinu 2000 fram í september 2009. Árið 2000 var fjöldi aðfluttra erlendra ríkisborgara 2.462, árið 2005 hafði peim fjölgað í 4.680, árið 2008 voru peir 7.471 en í september árið 2009 hafði peim fækkað í 2.793. Ef aðeins er athugað hversu margir með pólskt ríkisfang fluttust til Íslands á sama tímabili pá voru peir alls 353 árið 2000, 1.539 árið 2005, 3.885 árið 2008 og 1.065 árið 2009 (Hagstofa Íslands, 2009a). 


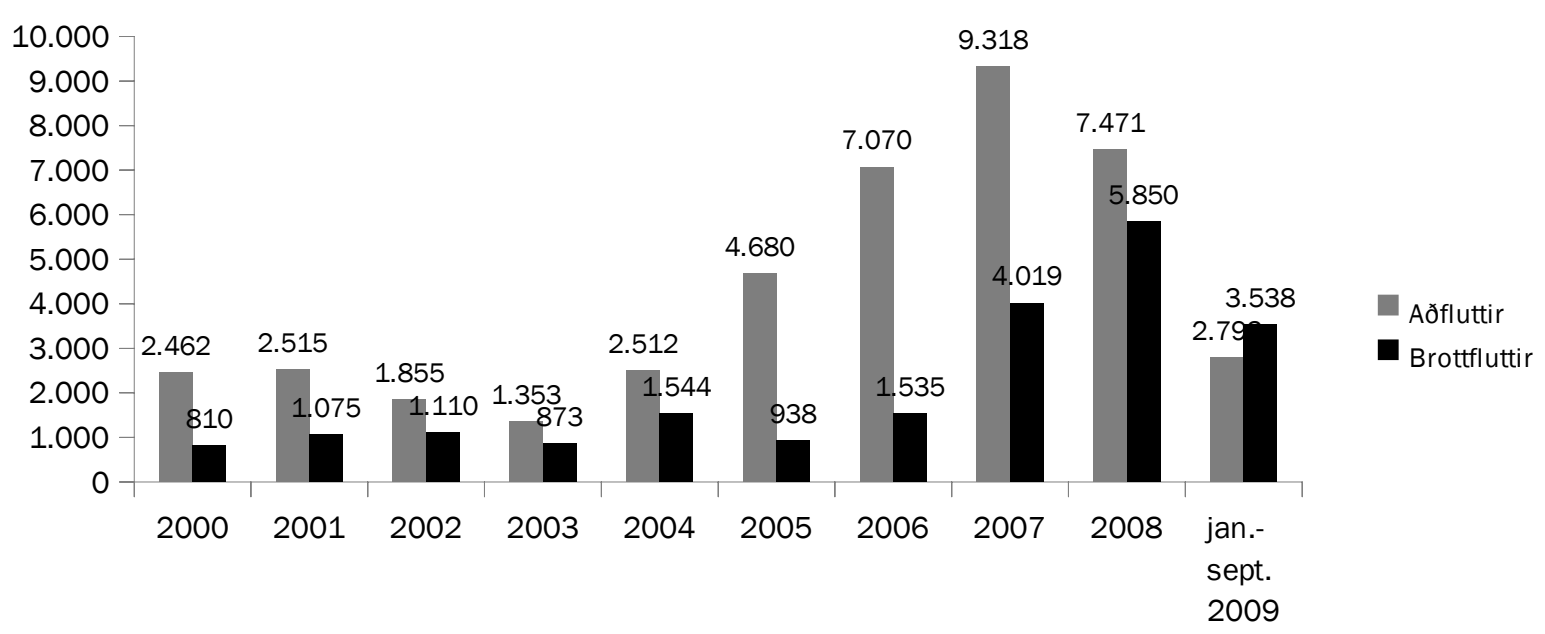

Mynd 1. Fjöldi aðfluttra og brottfluttra erlendra ríkisborgara á Íslandi frá 2000 til september 2009.

Prátt fyrir pessa fjölgun erlendra ríkisborgara á Íslandi setti ríkisstjórn Íslands ekki fram heildræna stefnu um aðlögun innflytjenda fyrr en í ársbyrjun 2007. Meginmarkmið peirrar stefnu er að tryggja sem best að allir íbúar landsins njóti jafnra tækifæra og verði virkir pátttakendur í samfélaginu á sem flestum sviðum mannslífsins (félags- og tryggingamálaráðuneyti, 2007). Á sama ári voru íslensk stjórnvöld gagnrýnd af ECRI (European Commission against Racism and Intolerance) meðal annars fyrir pað að atvinnurekendur gæfu út tímabundin atvinnuleyfi fyrir pá erlendu ríkisborgara sem ekki væru hluti af EES svæðinu. Pað eitt gæti ýtt undir mismunun sem væri sérstaklega viðsjárvert á samdráttartímum (ECRI - European Commission against Racism and Intolerance, 2007). Athygli vekur að í stefnu íslenskra stjórnvalda er talað um aðlögun innflytjenda að íslensku samfélagi án pess að skilgreint sé nánar hvað átt er við. Castles og Miller (2003: 249) segja að skipta megi ríkjum í prennt eftir pví hvort innan peirra sé við lýði aðgreiningar eða útilokunarstefna (differential exclusionary model), samlögun (assimilation) eða fjölmenningarstefna (multiculturalism). Í stuttu máli snýst aðgreiningar eða útilokunarstefna um pað að lítill vilji eða jafnvel andstaða er við pað að hleypa innflytjendum inn í ríkið sem ekki eiga uppruna sinn að rekja til pess. Samlögunarstefna snýst um að innflytjendur aðlagist pví samfélagi sem peir flytja til, taki upp siði pess og hefðir og láti af sínum eigin. Hlutverk ríkisvaldsins par sem samlögunarstefnu er fylgt er að móta stefnu til pess að auðvelda innflytjendum að læra tungumálið í pví ríki sem peir setjast að í og að taka pátt í pví kerfi sem pegar er til staðar. Fjölmenningarstefna snýst um að innflytjendur hafi sömu réttindi og peir sem fyrir eru í landinu en haldi á sama tíma í eigin siði og venjur svo lengi sem pau stangast ekki á við pau lög sem fyrir eru í landinu og ákveðin grundvallargildi samfélagsins. Í stefnu stjórnvalda má lesa á milli línanna að hugtakið aðlögun er notað í svipaðri merkingu og samlögun par sem aðlögunarhugtakið fjallar í meginatriðum um pátttöku innflytjenda í íslensku skólakerfi, íslenskukennslu 
fyrir innflytjendur og útfærslu á henni. Í peirri umfjöllun sem hér fer á eftir er hugtakið aðlögun notað í sömu merkingu og samlögun. Pess utan er tæpt á nokkrum páttum í stefnu stjórnvalda er varða innflytjendur og má par nefna aðgengi peirra að heilbrigðispjónustu, atvinnupátttöku og hvernig stuðla eigi að pví að innflytjendur verði virkir pátttakendur í íslensku samfélagi. Í stefnu íslenskra stjórnvalda er lítið rætt um leiðir eða úrræði í peim efnum en Eiríkur Bergmann Einarsson (2007: 87) hefur eftir embættismanni hjá félags- og tryggingamálaráðuneytinu að stefnan hafi helst að geyma staðfestingu á pví sem pegar var til staðar.

Aðlögun innflytjenda nær yfir víðara svið heldur en að læra nýtt tungumál. Samkvæmt Hans Mahnig (2005) snýst aðlögun innflytjenda meðal annars um pátttöku peirra í samfélaginu, sjálfsmynd peirra, tengsl peirra við heimalönd sín, samband peirra við pau ríki sem flutt er til og lögbundin réttindi innflytjenda í nýju ríki. Unnur Dís Skaptadóttir (2004) segir aðlögun innflytjenda vera flókið samspil milli menningar innflytjenda, tengsla peirra við upprunaland sitt og menningar heimamanna. Ekki er hægt að líta svo á að annaðhvort haldi innflytjendur siðum sínum eða láti af peim og taki upp siði og hefðir pess lands sem peir flytja til heldur er menning: „... síbreytileg blanda menningarpátta og strauma og pað er erfitt að segja hvar ein menning endar og önnur byrjar." (Unnur Dís Skaptadóttir, 2004: 589). Eitt af peim vandamálum sem parf að takast á við er neikvæð ímynd eða jafnvel fordómar heimamanna gagnvart innflytjendum. Wim van Oorschot og Wilfrek Uunk (2007) sýndu fram á tengsl milli efnahags- og félagslegrar stöðu heimamanna og viðhorfa peirra til innflytjenda par sem peir sem betur eru staddir efnahags- og félagslega hafa jákvæðari ímynd af innflytjendum samanborið við pá sem verr eru staddir. Peir notuðu gögn úr lífsgildakönnunum sem eru kallaðar European Value Survey (EVS) frá árunum 1999 og 2000 par sem peir tóku fyrir eftirfarandi 18 ríki: Frakkland, Bretland, Pýskaland, Austurríki, Ítalíu, Spán, Portúgal, Grikkland, Holland, Belgíu, Danmörku, Svípjóð, Finnland, Írland, Pólland, Tékkland, Slóvakíu og Ungverjaland. Niðurstaða peirra var sú að viðhorf heimamanna til innflytjenda sé að hluta til tengd pví hversu mikla samkeppni um störf peir upplifa að peir séu í gagnvart innflytjendum og að hluta til tengd almennum lífsgildum og viðhorfum um samfélagslegan jöfnuð. Peir sem aðhyllast gildi um jöfnuð í samfélaginu líta frekar á innflytjendur sem hluta af samfélaginu sem eigi að njóta sömu réttinda og aðrir samfélagspegnar.

Pegar lögbundin réttindi innflytjenda eru skoðuð á Íslandi má sjá að innflytjendalöggjöfin er að mestu leyti byggð á danskri fyrirmynd og að hluta til á peirri norsku auk löggjafar sem Ísland hefur purft að taka upp vegna aðildar að EES (sjá t.d. Ari Kl. Jónsson, 2008 og Eiríkur Bergmann Einarsson, 2007). Danska innflytjendalöggjöfin, sem er ein sú strangasta í Evrópu, einkennist af pví að gera fólki utan EES svæðisins pað afar erfitt að flytja til Danmerkur og petta hefur íslenska ríkið tekið upp. Auk pess hefur Ísland strangari löggjöf heldur en Danir hvað varðar hælisleitendur par sem almennt er ekki tekið á móti hælisleitendum á Íslandi (Eiríkur Bergmann Einarsson, 2007). Íslenska innflytjendalöggjöfin skiptist í tvo hluta, annars 
vegar í löggjöf sem ríkið hefur purft að gangast undir vegna aðildar að EES samningnum og hins vegar í löggjöf er varðar innflytjendur sem búa utan EES svæðisins. Svo virðist sem löggjöf íslenskra stjórnvalda um innflytjendur utan EES svæðisins stjórnist fyrst og fremst af pví hversu mikil pörf er fyrir vinnuafl par sem innflytjendur geta ekki komið til landsins öðruvísi en að vera pegar komnir með atvinnu og jafnframt er pað í höndum atvinnurekenda að sækja um atvinnuleyfi (Ari Kl. Jónsson, 2008).

Hugsanlega er hægt að halda pví fram að ströng innflytjendalöggjöf og aðlögun innflytjenda á Íslandi skipti ekki máli pegar til lengri tíma litið, par sem innflytjendum er velkomið að koma og búa í landinu meðan næg atvinna er í boði, en pegar kreppir að sé pess vænst að peir flytji annað. Sú stefna sem felst í að veita innflytjendum tímabundið atvinnuleyfi par sem gengið er út frá að hægt sé að nota vinnuaflið á meðan næg atvinna er til staðar hefur ekki gengið upp. Í Pýskalandi var til dæmis sú stefna að flytja inn ódýrt vinnuafl gefin upp á bátinn upp úr 1970, ekki einungis vegna olíukreppunnar heldur einnig vegna pess að raunin varð sú að erlendir verkamenn settust í auknum mæli að í landinu með fjölskyldum sínum og stefnan pví fallin um sjálfa sig (Castles og Miller, 2003).

Pað er pví ekki hægt að gera ráð fyrir pví að allir innflytjendur sem sest hafa að á Íslandi síðasta áratug hverfi af landi brott pegar kreppir að enda hefur pað sýnt sig að frá janúar til september 2009 voru aðfluttar konur með erlent ríkisfang 196 talsins umfram pær brottfluttu. Á pessu tímabili fluttust 1.317 konur til Íslands en 1.121 fluttist frá landinu. Hjá körlum með erlent ríkisfang var pessu öfugt farið par sem fleiri fluttu af landi brott heldur en komu til landsins, eða 2.417 á móti 1.476. Heildarfjöldi brottfluttra umfram aðflutta var pví 745 alls á pessum tíma (Hagstofa Íslands, 2009a).

Fjölgun innflytjenda á Íslandi frá síðustu aldamótum er staðreynd og pví fylgja ýmis verkefni sem stjórnvöld og aðrir landsmenn purfa að takast á við. Í fyrrnefndri skýrslu ECRI frá árinu 2007 komu fram athugasemdir um að nokkuð skorti á rannsóknir um mismunun og stöðu minnihlutahópa á Ísland, par með talið á stöðu innflytjenda (ECRI - European Commission against Racism and Intolerance, 2007). Nokkrar rannsóknir hafa pó verið gerðar og verður drepið á nokkrum peirra hér. Friðrik H. Jónsson (2003) birti niðurstöður úr lífsgildakönnun frá árinu 1999 par sem spurt var um afstöðu til útlendinga í 33 ríkjum. Helstu niðurstöður hans voru að í samanburði við aðrar Evrópupjóðir væru Íslendingar nokkuð velviljaðir í garð útlendinga. Árið 2006 lagði Capacent fyrir nokkrar spurningar í Pjóðarpúlsi sínum um afstöðu Íslendinga til innflytjenda (Capacent, 2006). Í peirri könnun kom meðal annars fram að um helmingur pjóðarinnar $(51,4 \%)$ var mjög eða frekar jákvæður gagnvart pví að leggja áherslu á að Ísland væri fjölmenningarsamfélag, priðjungur var hlutlaus og tæplega 15\% voru mjög eða frekar neikvæð gagnvart pví. Jafnframt voru íbúar í Reykjavík hlutfallslega oftar jákvæðir gagnvart pví að Ísland væri fjölmenningarsamfélag samanborið við pá sem bjuggu utan Reykjavíkur. Árið 2009 
gerði Capacent svo könnun fyrir félags- og tryggingamálaráðuneyti Íslands par sem spurt var um viðhorf pátttakenda til mismununar á Íslandi (Félags- og tryggingamálaráðuneyti, 2009). Samkvæmt niðurstöðum töldu 56,9\% svarenda pað vera mjög eða frekar algengt að fólki væri mismunað eða аð pað væri áreitt á grundvelli kynpáttar og pjóðernis og um fjórðungur sagðist hafa orðið vitni að pví. Einnig kom fram að 68,4\% töldu að kynpáttur eða uppruni gæti haft neikvæð áhrif á möguleika jafn hæfra umsækjenda um starf. Fleiri rannsóknir má nefna sem gerðar hafa verið. Árið 2007 birtu Hilda Jana Gísladóttir og Jóhann Ásmundsson niðurstöður úr rannsókn um stöðu innflytjenda á Norðurlandi. Árið 2004 stóð Félagsvísindastofnun Háskóla Íslands fyrir rannsókn á viðhorfum innflytjenda sem búa á Vestfjörðum og á Austurlandi (Heiður Hrund Jónsdóttir, Hildur Svavarsdóttir, Kristín Erla Harðardóttir og Friðrik H. Jónsson, 2004) og sama ár birti Kristín Loftsdóttir (2004) niðurstöđur úr rannsókn á pví hvað hugtakið kynpáttur merkir í huga Íslendinga. Á pessu ári birtust rannsóknarniðurstöður sem pær Hallfríður Pórarinsdóttir, Sólveig H. Georgsdóttir og Berglind L. Hafsteinsdóttir (2009) unnu par sem rætt var við innflytjendur um upplifun peirra á efnahagskreppunni sem skall á síðasta haust.

Sjá má á pessu stutta yfirliti að pær rannsóknir sem gerðar hafa verið hér á landi og snúast um innflytjendur hafa í meginatriðum verið um viðhorf Íslendinga (ýmist innfæddra eða íslenskra ríkisborgara) til innflytjenda almennt, um fordóma Íslendinga gagnvart fólki af erlendum uppruna og upplifun innflytjendanna sjálfra. Í greininni sem hér er rituð er viðfangsefnið að hluta til pað sama en pó er lögð áhersla á viðhorf Íslendinga til innflytjenda á vinnumarkaði og er greininni sem slíkri ætlað að vera viðbót í rannsóknarflóruna um innflytjendur á Íslandi en jafnframt innlegg í fræðilega jafnt sem opinbera umræðu um innflytjendamál á Íslandi.

Í greininni eru birtar niðurstöður úr fyrirliggjandi gögnum sem Félagsvísindastofnun Háskóla Íslands hefur safnað á Íslandi síðustu ár sem og niðurstöður úr könnun Rannsóknamiðstöðvar Háskólans á Bifröst (RHB) sem gerð var í september 2008 par sem íslenskir ríkisborgarar voru spurðir um viðhorf sín til innflytjenda á Íslandi. Gögn Félagsvísindastofnunar eru annars vegar úr könnun sem gerð var í 23 ríkjum á árunum 2004 til 2005 (European Social Survey, e.d.; skammstafað sem ESS) og hins vegar úr lífsgildakönnun sem náði til 33 ríkja og var unnin á Íslandi árið 1999 (World Value Survey, e.d.; skammstafað sem EVS/WVS). Hér eftir verður vísað í pessar kannanir með skammstöfun peirra. Skipta má umfjölluninni í tvennt par sem annars vegar var spurt um hversu mörgum innflytjendum ætti að hleypa til Íslands og hins vegar spurt út í pátttöku peirra á íslenskum vinnumarkaði. Niðurstöður úr könnun RHB og samanburðargögn leiða líkur að pví að hætt sé við neikvæðari afstöðu til innflytjenda eftir að efnahagskreppa skall á landið af fullum punga í október 2008 og hafði í för með sér aukið atvinnuleysi á Íslandi. 


\section{Rannsóknasnið}

Könnun RHB innihélt meðal annars spurningar sem notaðar voru í ESS og WVS/EVS og höfðu áður verið lagðar fyrir á Íslandi og í öðrum Evrópulöndum en pað býður upp á samanburð bæði í tíma og í rúmi. Könnun RHB var lögð fyrir 969 manna tilviljunarúrtak meðal íslenskra ríkisborgara dagana 3. september til 23. september árið 2008 og var svarhlutfall 58,0\%.

Fyrstu fjórar spurningarnar sem teknar eru fyrir í pessari grein eru um afstöðu pátttakenda til pess í hve miklum mæli ætti að leyfa fólki að flytjast til Íslands. Fyrst var spurt um fólk sem er af sama kynpætti eða hefur svipaðan menningarlegan uppruna og flestir Íslendingar. Önnur spurningin snerist um fólk af ólíkum kynpætti eða með ólíkan menningarlegan uppruna. Næst var spurt um fólk frá fátækari löndum utan Evrópu og að lokum um fólk frá fátækari löndum innan Evrópu. Prjár af pessum spurningum voru lagðar fyrir Íslendinga í könnun ESS árið 2005 og allar fjórar í 22 öðrum ríkjum árið 2002 og eru niðurstöður bornar saman á milli ríkja og á milli ára á Íslandi.

Næstu premur spurningum var ætlað að mæla afstöðu til pess hversu gott eða slæmt pað væri fyrir íslenskt samfélag að fólk frá öðrum löndum flyttist hingað og voru pessar spurningar einnig hluti af ESS, bæði á Íslandi árið 2005 og í 22 öðrum ríkjum árið 2002. Spurningarnar snerust um hvort pað væri gott eða slæmt fyrir efnahag Íslands að fólk frá öðrum löndum flyttist til landsins, hvort pað auðgaði eða græfi undan íslensku menningarlífi og hvort pað gerði Ísland að betri eða verri stað að búa á. Áttunda spurningin sem fjallað er um í pessarri grein snýst um pað hvort betra sé að innflytjendur viðhaldi sínum sérstöku siðum og venjum eða láti af peim og tileinki sér siði pess lands sem peir flytja til. Pessi spurning var einnig hluti af WVS/EVS á Íslandi og í 32 öðrum Evrópuríkjum árið 1999.

Að lokum er fjallað um niðurstöður úr fjórum spurningum par sem spurt var um afstöðu til innflytjenda á vinnumarkaði. Svarendur voru beðnir um að svara hversu sammála eða ósammála peir væru pví að atvinnurekendur ættu að ráđa Íslendinga í vinnu frekar en aðra pegar atvinna er af skornum skammti, hvort innflytjendur væru í samkeppni við Íslendinga um störf á íslenskum vinnumarkaði, hvort fjölgun innflytjenda eða farandverkamanna á Íslandi lækki almennt meðallaun á Íslandi og hvort fjölgun peirra lækki meðallaun í peim atvinnugreinum sem peir starfa í á Íslandi.

Gerð var fjölbreytuaðhvarfsgreining á svörum við öllum spurningunum að undanskildum síðustu tveimur sem voru annars vegar um pað hvort fjölgun innflytjenda eða farandverkamanna á Íslandi lækki almennt meðallaun á Íslandi og hins vegar um pað hvort pað lækki meðallaun í peim atvinnugreinum sem peir starfa helst í. Fjölbreytuaðhvarfsgreining felur í stuttu máli í sér að tengsl hverrar frumbreytu eru einangruð við fylgibreytu par sem fylgibreytur eru svör við peim spurningum sem fjallað er um hér að ofan. Ef pað eru til dæmis tengsl á milli kyns og menntunar (frumbreytur) við afstöðu til pess hvort fjölgun innflytjenda auðgi eða 
grafi undan íslensku menningarlífi er hægt að skoða annars vegar tengsl kyns við afstöðuna að teknu tilliti til menntunar og hins vegar tengsl menntunar við afstöðu til spurningarinnar eftir að búið er að taka tillit til kyns. Með peim hætti er leitast við að koma í veg fyrir að fjallað sé um sýndartengsl sem gætu verið tilkomin vegna skiptingar í hópa. Segjum sem svo að ekki sé munur eftir menntun en að karlar séu frekar peirrar skoðunar að fjölgun innflytjenda grafi undan íslensku menningarlífi og að peir séu jafnframt í meirihluta peirra sem hafa meiri menntun. Ef ekki væri notuð fjölbreytuaðhvarfsgreining gæti litið út fyrir að pað væru einnig tengsl milli menntunar og afstöðu til innflytjenda, en með pví að skoða tengslin að teknu tilliti til menntunar er komið í veg fyrir pað.

Í peim fjölbreytuaðhvarfsgreiningum sem gerðar eru í pessari grein eru frumbreyturnar menntun, kyn, búseta, starf, aldur og afstaða til pess hversu miklu eða litlu máli pað skiptir að bæta lífskjör útlendinga á Íslandi ${ }^{1}$. Menntun var notuð sem frumbreyta par sem áhugi var á að kanna hvort peir sem væru með meiri menntun hefðu almennt jákvæðari afstöðu gagnvart innflytjendum samanborið við pá sem hafa minni menntun. Menntun fólks var flokkuð í grunnskólamenntun, bóklega framhaldsskólamenntun, iðnmenntun og háskólamenntun. Par sem spurt var um menntun sem raðbreytu, par sem menntunarflokkarnir hafa ekki eiginlega tölulega merkingu heldur segja til um hvort menntun sé meiri eða minni, voru búnar til vísibreytur par sem viðmiðunarhópurinn voru peir sem voru með grunnskólamenntun. раð pýðir að ef marktækur munur kom fram eftir menntun var samanburðurinn alltaf við pá sem voru með grunnskólamenntun. Ef marktækni kom fram meðal peirra sem voru með háskólamenntun pýðir pað að munur var á milli háskólamenntaðra og grunnskólamenntaðra, burtséð frá peim sem voru með bóklega framhaldsskólamenntun eða iðnmenntun. Einnig var áhugi á pví að kanna hvort munur væri á afstöðu kynjanna og hvort pað væri munur á svörum pátttakenda eftir búsetu par sem samanburðurinn er á milli peirra sem bjuggu á höfuðborgarsvæðinu og utan pess. Ákveðið var að greina afstöðu svarenda eftir starfi par sem innflytjendur hafa helst verið í sérhæfðum og ósérhæfðum verkamannastörfum hér á landi og pví vert að kanna hvort íslenskir ríkisborgarar í sömu atvinnugreinum upplifðu innflytjendur frekar sem samkeppni á vinnumarkaði og hefðu pví neikvæðari afstöðu til peirra. Flokkun eftir starfi var grundvölluð á ÍSTARF-flokkun (Hagstofa Íslands, 2009c) par sem æðstu embættismenn, sérfræðingar og sérmenntað starfsfólk var notað sem viðmiðunarhópur en auk pess voru flokkarnir prír:

- peir sem starfa við pjónustu-, skrifstofu- og afgreiðslustörf

- iðnaðarmenn, véla- og vélgæslufólk, bændur og sjómenn

- ósérhæft starfsfólk

Greint var eftir aldri til að kanna pá tilgátu hvort eldra fólk hafi neikvæðari afstöðu til innflytjenda en yngra fólk og að lokum eftir afstöðu til pess hvort pað skipti máli

1 Sjá má tíðnitöflur fyrir allar frumbreyturnar í viðaukanum. 
að bæta lífskjör útlendinga á Íslandi. Svarmöguleikarnir við síðustu spurningunni voru fimm par sem einn merkti að pað skipti mjög litlu máli og fimm að pað skipti mjög miklu máli. Notuð er línuleg fjölbreytuaðhvarfsgreining í öllum tilfellum að undanskilinni spurningunni um pað hvort innflytjendur ættu að viðhalda eigin siðum eða hefðum en par er notuð ólínuleg aðhvarfsgreining par sem svarkvarðinn er á nafnkvarða. Í niðurstöðukafla eru niðurstöður fjölbreytuaðhvarfsgreiningar birtar í töflum par sem sett er fram hallatala (b) og staðalfrávik hennar. Hallatalan segir til um pað hversu mikið fylgibreytan hækkar eða lækkar við hækkun eða lækkun á frumbreytum. Ef hallatalan er marktæk merkir pað að hægt sé að álykta um að tengsl séu á milli frumbreytu og fylgibreytu og er marktækni auðkennd með stjörnu(m) og plúsmerki. Ef hallatalan er marktæk miðað við 99,999\% vissu er hún auðkennd með premur stjörnum (***), 99,99\% vissa með tveimur stjörnum (**), 95\% vissa með einni stjörnu (*) og 90\% vissa með plúsmerki (+). Í töflum með niðurstöðum fjölbreytuaðhvarfsgreiningar eru einnig birtar tölur fyrir staðalvillu og fasta. Fasti er skurðpunktur hallatölu við y-ás pegar frumbreytan hefur gildið 0 og staðalvillan segir til um hversu mikil dreifing er í tengslum frumbreytu og fylgibreytu.

\subsection{Niðurstöður: Hversu mörgum innflytjendum á að leyfa að flytja til landsins?}

Í spurningunum fjórum um pað hversu mörgum innflytjendum ætti að leyfa að flytja til Íslands var fyrst spurt um pá sem eru af sama kynpætti eða hafa svipaðan menningarlegan uppruna og flestir Íslendingar, pví næst er spurt um pá sem hafa af ólíkan menningarlegan uppruna, síðan um pá sem koma frá fátækari löndum utan Evrópu og að lokum um pá sem koma frá fátækari löndum innan Evrópu. Svarmöguleikar voru fjórir; að leyfa mörgum að flytjast til Íslands, leyfa nokkrum, leyfa fáum og leyfa engum.

Á mynd 2 má sjá hlutfall peirra sem svöruðu pessum fjórum spurningum á pann veg að leyfa ætti mörgum að flytja til Îslands og í premur peirra má sjá samanburð við sömu spurningar og pær sem lagðar voru fyrir í ESS könnun Félagsvísindastofnunar árið 2005. Mestur var stuðningurinn við pað að leyfa mörgum sem eru af sama kynpætti eða hafa svipaðan menningarlegan uppruna að flytja til Íslands, bæði árið 2005 (47,3\%) og 2008 (39,5\%). Árið 2008 var stuðningurinn minnstur við pað að leyfa mörgum frá fátækari löndum utan Evrópu að flytjast til Íslands (24,9\%) en árið 2005 var stuðningurinn minnstur við pað að leyfa mörgum af ólíkum kynpætti eða sem hafa ólíkan menningarlegan uppruna að flytjast hingað (28,7\%). Í peim premur spurningum sem einnig voru lagðar fyrir 2005 hefur stuðningur við pað að leyfa mörgum að flytja til Íslands farið minnkandi í öllum tilfellum. 

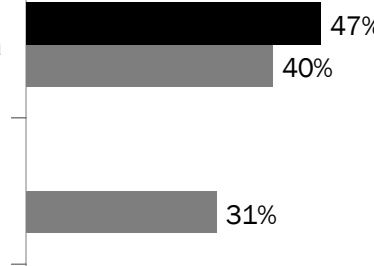

Frá fátækari löndum innan Evrópu

Frá fátækari löndum utan Evrópu
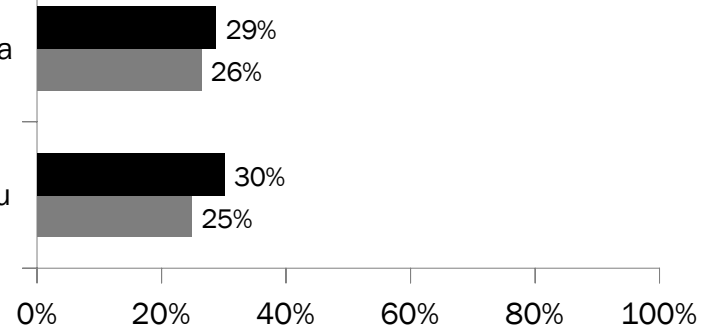

Mynd 2. Deir sem svöruðu að leyfa ætti mörgum að flytjast til Íslands eftir pví hvort innflytjendur séu af sama kynpætti eða hafi svipaðan menningarlegan uppruna og Íslendingar, séu af ólíkum kynpætti eða hafa ólíkan menningarlegan uppruna, komi frá fátækari löndum utan eða innan Evrópu. Samanburdur á milli 2005 og 2008.

Í töflu 1 má sjá niðurstöður aðhvarfsgreiningar par sem fylgibreyturnar eru afstaða til pessara fjögurra spurninga um hversu mörgum ætti að leyfa að flytja til Íslands og frumbreyturnar voru menntun, kyn, búseta, starf, aldur og viðhorf til pess hvort vinna ætti að pví að bæta lífskjör útlendinga á Íslandi. Fylgibreytan um pað hversu mörgum ætti að leyfa að flytja til Íslands er með gildi frá einum upp í fjóra par sem einn merkir að leyfa eigi mörgum að flytja til Íslands og fjórir að leyfa engum.

Í öllum pessum fjórum spurningum var munur á viðhorfum fólks eftir menntun par sem peir sem voru með háskólamenntun voru frekar hlynntir pví að leyfa ætti fleirum að flytja til Íslands samanborið við pá sem eru með grunnskólamenntun. Jafnframt var munur eftir pví hvaða viðhorf fólk hafði til pess hvort bæta ætti lífskjör útlendinga á Íslandi par sem peir sem töldu pað skipta frekar eða mjög miklu máli voru frekar peirrar skoðunar að leyfa ætti mörgum að flytja til landsins miðað við pá sem töldu pað skipta frekar eða mjög litlu máli að bæta lífskjör útlendinga á Íslandi.

Sömu spurningar voru lagðar fyrir í ESS könnuninni í 22 ríkjum árið 2002 og í töflu 2 má sjá afstöðu Íslendinga borna saman við afstöðu fólks í öðrum Evrópulöndum og í Ísrael sem voru meðal peirra sem svöruðu pví að leyfa ætti mörgum að flytja til landsins. Íslendingar eru í öllum tilfellum í hópi ríkja par sem hlutfallslega flestir eru hlynntir pví að leyfa eigi mörgum að flytja til landsins hvort sem um er að ræða fólk af sama kynpætti eða sem hefur svipuðan menningarlegum uppruna, fólk af ólíkum kynpáttum eða fólk frá fátækari löndum innan eða utan Evrópu. Á sama tíma hefur, á pessu priggja ára tímabili, dregið úr jákvæðni Íslendinga gagnvart pví að hleypa eigi mörgum til landsins. 
Tafla 1. Að hvaða marki ætti að leyfa fólki að flytjast hingað til lands sem er af sama kynpætti eða sem hefur svipaðan menningarlegan uppruna og flestir Íslendingar, sem er af ólíkum kynpætti eða hefur ólíkan menningarlegan uppruna eða sem er frá fátækari löndum innan eða utan Evrópu? (1=leyfa mörgum, 2=leyfa nokkrum, 3=leyfa fáum, 4=leyfa engum). Greint eftir menntun, kyni, búsetu, starfi, aldri og hvort að vinna ætti að pví að bæta lífskjör útlendinga á Íslandi. 2008.

\begin{tabular}{|c|c|c|c|c|}
\hline & $\begin{array}{c}\text {... af sama } \\
\text { kynpætti } \\
\text { eða hefur } \\
\text { svipaðan } \\
\text { menningar- } \\
\text { legan } \\
\text { uppruna }\end{array}$ & $\begin{array}{c}\text {... af ólíkum } \\
\text { kynpætti } \\
\text { eða hefur } \\
\text { ólíkan } \\
\text { menningar- } \\
\text { legan } \\
\text { uppruna }\end{array}$ & $\begin{array}{c}\text {... frá } \\
\text { fátækari } \\
\text { löndum } \\
\text { innan } \\
\text { Evrópu }\end{array}$ & $\begin{array}{c}\text {... frá } \\
\text { fátækari } \\
\text { löndum } \\
\text { utan Evrópu }\end{array}$ \\
\hline & B & B & B & B \\
\hline & \multicolumn{3}{|c|}{ (Staðalvilla) (Staðalvilla) (Staðalvilla) } & (Staðalvilla) \\
\hline Fasti & 2,534 & 2,901 & 2,660 & 2,868 \\
\hline Grunnskólamenntun & Viðmið & & & \\
\hline Bókleg framhaldsskólamenntun & $\begin{array}{c}-, 002 \\
(0,115)\end{array}$ & $\begin{array}{c}-, 067 \\
(0,129)\end{array}$ & $\begin{array}{c}, 132 \\
(0,123)\end{array}$ & $\begin{array}{l}, 107 \\
(0,138)\end{array}$ \\
\hline Iðnmenntun & $\begin{array}{c}-, 004 \\
(0,130)\end{array}$ & $\begin{array}{c}-, 037 \\
(0,146)\end{array}$ & $\begin{array}{c}, 073 \\
(0,140)\end{array}$ & $\begin{array}{c}, 144 \\
(0,154)\end{array}$ \\
\hline Háskólamenntun & $\begin{array}{l}-, 271 * \\
-0,12\end{array}$ & $\begin{array}{l}-, 343 * \\
(0,130)\end{array}$ & $\begin{array}{l}-, 319 * \\
(0,125)\end{array}$ & $\begin{array}{l}-, 381 * \\
(0,140)\end{array}$ \\
\hline Karlar (viðmið=konur) & $\begin{array}{c}, 004 \\
(0,086)\end{array}$ & $\begin{array}{c}, 113 \\
(0,096)\end{array}$ & $\begin{array}{c}, 022 \\
(0,093)\end{array}$ & $\begin{array}{c}, 199 \\
(0,103)\end{array}$ \\
\hline Höfuðborgarsvæði (viðmið=landsbyggð) & $\begin{array}{c}, 049 \\
(0,078)\end{array}$ & $\begin{array}{c}, 046 \\
(0,087)\end{array}$ & $\begin{array}{c}, 142 \\
(0,084)\end{array}$ & $\begin{array}{c}, 135 \\
(0,093)\end{array}$ \\
\hline $\begin{array}{l}\text { Æðstu embættismenn, sérfræðingar og } \\
\text { sérmenntað starsfsfólk }\end{array}$ & Viðmið & & & \\
\hline Pjónustustörf, skrifstofu- og &,- 087 &,- 090 & ,022 & ,012 \\
\hline afgreiðslufólk & $(0,106)$ & $(0,120)$ & $(0,116)$ & $(0,129)$ \\
\hline Iðnaðarmenn, véla- og vélgæslufólk, & ,077 &, 040 & , 168 &,- 073 \\
\hline bændur og sjómenn & $(0,130)$ & $(0,145)$ & $(0,141)$ & $(0,158)$ \\
\hline Ósérhæft starfsfólk & $\begin{array}{c}0,062 \\
(0,164)\end{array}$ & $\begin{array}{c}-, 002 \\
(0,186)\end{array}$ & $\begin{array}{c}, 093 \\
(0,174)\end{array}$ & $\begin{array}{c}-, 043 \\
(0,195)\end{array}$ \\
\hline Aldur & $\begin{array}{c}, 000 \\
(0,003)\end{array}$ & $\begin{array}{c}, 004 \\
(0,003)\end{array}$ & $\begin{array}{c}-, 001 \\
(0,003)\end{array}$ & $\begin{array}{c}, 003 \\
(0,003)\end{array}$ \\
\hline $\begin{array}{l}\text { Vinna ætti að pví að bæta lífskjör } \\
\text { útlendinga á Íslandi }\end{array}$ & $\begin{array}{l}-, 179 * * * \\
(0,030)\end{array}$ & $\begin{array}{c}-, 219 * * * \\
(0,033)\end{array}$ & $\begin{array}{l}-, 198^{* * *} \\
(0,032)\end{array}$ & $\begin{array}{c}-, 234^{* * *} \\
-0,04\end{array}$ \\
\hline
\end{tabular}


Tafla 2. Samanburður á hlutfalli peirra sem segja að leyfa ætti mörgum sem eru af sama kynpætti eða sem hafa svipaðan menningarlegan uppruna en flestir heimamenn að flytjast til landsins, sem eru af ólíkum kynpætti eða hafa ólíkan menningarlegan uppruna eða eru frá fátækari löndum utan og innan Evrópu. Samanburđur á milli 23 Evrópuríkja.

\begin{tabular}{|c|c|c|c|c|}
\hline & $\begin{array}{c}\text { Af sama } \\
\text { kynpætti } \\
\text { eða hafa } \\
\text { svipaðan } \\
\text { menningar- } \\
\text { legan } \\
\text { uppruna }\end{array}$ & $\begin{array}{c}\text { Af öðrum } \\
\text { kynpætti } \\
\text { eða hafa } \\
\text { ólíkan } \\
\text { menningar- } \\
\text { legan } \\
\text { uppruna }\end{array}$ & $\begin{array}{c}\text { Frá fátækari } \\
\text { löndum } \\
\text { utan } \\
\text { Evrópu }\end{array}$ & $\begin{array}{c}\text { Frá fátækari } \\
\text { löndum } \\
\text { innan } \\
\text { Evrópu }\end{array}$ \\
\hline Ísland 2008 & $39,5 \%$ & $26,3 \%$ & $24,9 \%$ & $30,5 \%$ \\
\hline Ísland 2005 & $49,5 \%$ & $30,1 \%$ & $31,1 \%$ & \\
\hline \multicolumn{5}{|l|}{ Önnur Evrópuríki 2002: } \\
\hline Ísrael & $56,5 \%$ & $27,0 \%$ & $27,8 \%$ & $29,7 \%$ \\
\hline Svípjóð & $30,4 \%$ & $17,0 \%$ & $22,6 \%$ & $24,7 \%$ \\
\hline Írland & $22,9 \%$ & $16,9 \%$ & $16,7 \%$ & $17,8 \%$ \\
\hline Ítalía & $22,7 \%$ & $12,9 \%$ & $16,5 \%$ & $17,6 \%$ \\
\hline Ungverjaland & $21,2 \%$ & $11,8 \%$ & $12,6 \%$ & $16,0 \%$ \\
\hline Danmörk & $20,9 \%$ & $11,5 \%$ & $12,3 \%$ & $14,3 \%$ \\
\hline Sviss & $20,4 \%$ & $11,2 \%$ & $12,1 \%$ & $13,7 \%$ \\
\hline Spánn & $19,8 \%$ & $11,1 \%$ & $11,8 \%$ & $12,9 \%$ \\
\hline Noregur & $19,7 \%$ & $10,5 \%$ & $10,9 \%$ & $12,9 \%$ \\
\hline Pýskaland & $19,1 \%$ & $10,1 \%$ & $9,9 \%$ & $12,3 \%$ \\
\hline Lúxemborg & $18,3 \%$ & $9,7 \%$ & $9,9 \%$ & $12,3 \%$ \\
\hline Belgía & $14,7 \%$ & $8,5 \%$ & $9,2 \%$ & $10,1 \%$ \\
\hline Finnland & $13,7 \%$ & $8,4 \%$ & $8,7 \%$ & $9,9 \%$ \\
\hline Pólland & $13,5 \%$ & $7,7 \%$ & $8,5 \%$ & $9,1 \%$ \\
\hline Slóvenía & $11,2 \%$ & $7,5 \%$ & $7,5 \%$ & $8,8 \%$ \\
\hline Austurríki & $10,8 \%$ & $7,3 \%$ & $7,5 \%$ & $8,2 \%$ \\
\hline Bretland & $10,8 \%$ & $7,3 \%$ & $7,1 \%$ & $8,0 \%$ \\
\hline Frakkland & $10,0 \%$ & $6,9 \%$ & $6,9 \%$ & $7,8 \%$ \\
\hline Grikkland & $9,9 \%$ & $5,9 \%$ & $5,9 \%$ & $6,8 \%$ \\
\hline Tékkland & $9,4 \%$ & $5,4 \%$ & $5,5 \%$ & $5,7 \%$ \\
\hline Holland & $7,9 \%$ & $3,1 \%$ & $3,0 \%$ & $4,0 \%$ \\
\hline Portúgal & $6,2 \%$ & $3,0 \%$ & $2,9 \%$ & $3,4 \%$ \\
\hline Heildarhlutfall Evrópuríkja 2002 & $18,1 \%$ & $9,9 \%$ & $10,8 \%$ & $12,1 \%$ \\
\hline
\end{tabular}




\section{2. Ávinningur af innflytjendum}

Í peirri rannsókn sem hér er til umræðu voru lagðar prjár spurningar fyrir pátttakendur um ávinning pess fyrir íslenskt samfélag að fólk frá öðrum löndum flytjist til landsins. Fyrsta spurningin var um pað hvort peir teldu pað gott eða slæmt fyrir efnahag Íslands að fólk frá öðrum löndum flyttist hingað, næsta spurning snerist um pað hvort pað auðgi eða grafi undan menningarlífi á Íslandi og að lokum var spurt að pví hvort pað myndi gera Ísland að betri eða verri stað að búa á. Fólk var beðið um að svara á skalanum núll til tíu par sem núll táknaði að pað væri slæmt fyrir efnahaginn, græfi undan íslensku menningarlífi og gerði Ísland að verri stað til að búa á og tíu merkti að pað væri gott fyrir efnahaginn, auðgaði íslenskt menningarlíf og gerði Ísland að betri stað til að búa á. Pessar prjár spurningar voru einnig lagðar fyrir í ESS könnun Félagsvísindastofnunar árið 2005. Á mynd 3 má sjá að lítil sem engin breyting hefur orðið á viðhorfum fólks milli ára til pess hvort pað væri gott eða slæmt fyrir efnahag Íslands að fólk frá öðrum löndum flyttist til landsins par sem meðaltalið var 5,9 árið 2005 og 6,0 árið 2008. Munur var á meðaltölum milli áranna pegar spurt var hvort pað auðgaði eða græfi undan íslensku menningarlífi eða gerði Ísland að betri eða verri stað að búa á ef fólk frá öðrum löndum flyttist til Íslands par sem Íslendingar tóku heldur neikvæðari afstöðu árið 2008 heldur en 2005. Árið 2008 töldu fleiri að pað gerði Íslandi að verri stað að búa á og að pað græfi undan íslensku menningarlífi ef fólk frá öðrum löndum flyttist til Íslands heldur en árið 2005.

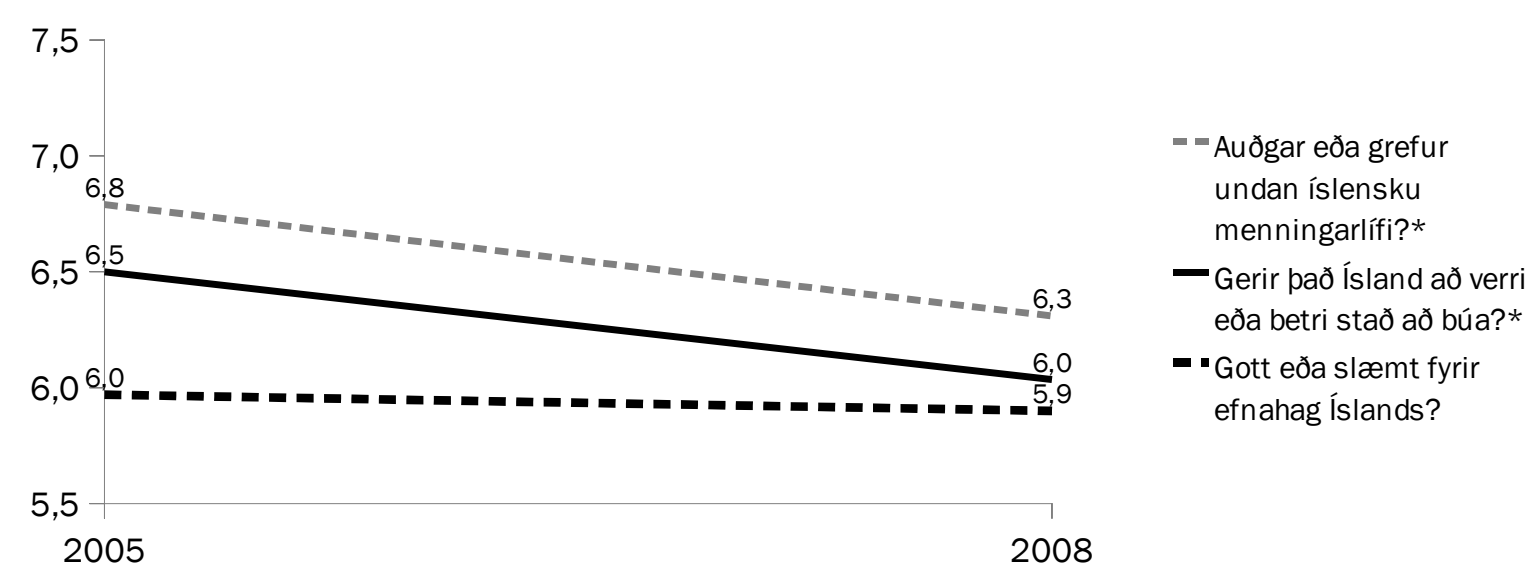

Mynd 3. Samanburður á meðaltölum árin 2005 og 2008 eftir pví hvort svarendur telji að pað sé gott eða slæmt fyrir efnahagslif Íslands að fólk flytjist til landsins, hvort pað auðgi eða grafi undan íslensku menningarlífi og hoort pað geri Ísland að verri eða betri stað að búa á. ${ }^{2}$ Myndin sýnir einungis skalann frá 5,5 upp i 7,5.

2 Notað var t-próf til að greina hvort marktækur munur væri á meðaltölum á milli ára miðað við $95 \%$ vissu. Marktækur munur er stjörnumerktur $\left.{ }^{*}\right)$. Gott eða slæmt fyrir efnahag Íslands: $2005 \mathrm{n}=$ $579, \mathrm{~s}=2,1 ; 2008 \mathrm{n}=562, \mathrm{~s}=2,3$. Auðgar eða grefur undan íslensku menningarlífi: $2005 \mathrm{n}=579, \mathrm{~s}=$ 6,$8 ; 2008 \mathrm{n}=562, \mathrm{~s}=2,5$. Gerir Ísland að betri eða verri stað að búa á: $2005 \mathrm{n}=579 \mathrm{~s}=6,5 ; 2008 \mathrm{n}=$ $562, \mathrm{~s}=2,5$. 
Tafla 3. Telur pú að pað sé almennt gott eða slæmt fyrir efnahag landsins að fólk frá öðrum löndum flytjist til pess (1=slæmt, 10=gott), að pað auðgi eða grafi undan íslensku menningarlífi (1=grefur undan, 10=auðgar), að pað geri Ísland að betri eða verri stað að búa á ef innflytjendum fjölgar (1=verri, 10=betri)? Greint eftir menntun, kyni, búsetu, starfi, aldri og pví hoort vinna ætti að poí að bæta lífskjör útlendinga á Íslandi. 2008.

\begin{tabular}{|c|c|c|c|}
\hline & $\begin{array}{c}\text {... gott eða } \\
\text { slæmt fyrir } \\
\text { efnahag } \\
\text { Íslands }\end{array}$ & $\begin{array}{c}\text {... auðgi eða } \\
\text { grafi undan } \\
\text { íslensku } \\
\text { menningar- } \\
\text { lífi }\end{array}$ & $\begin{array}{c}\text {... gerir } \\
\text { Ísland að } \\
\text { betri eða } \\
\text { verri stað að } \\
\text { búa á }\end{array}$ \\
\hline & $\begin{array}{c}\text { B } \\
\text { (Staðalvilla) }\end{array}$ & $\begin{array}{c}\text { B } \\
\text { (Staðalvilla) }\end{array}$ & $\begin{array}{c}\text { B } \\
\text { (Staðalvilla) }\end{array}$ \\
\hline Fasti & 3,559 & 4,592 & 4,246 \\
\hline $\begin{array}{l}\text { Grunnskólamenntun } \\
\text { Bókleg framhaldsskólamenntun }\end{array}$ & $\begin{array}{l}\text { Viðmið } \\
, 526 \\
(0,334)\end{array}$ & $\begin{array}{c}, 130 \\
(0,325)\end{array}$ & $\begin{array}{c}, 277 \\
(0,331)\end{array}$ \\
\hline Iðnmenntun & $\begin{array}{c}-, 026 \\
(0,371)\end{array}$ & $\begin{array}{c}-, 178 \\
(0,371)\end{array}$ & $\begin{array}{c}-, 025 \\
(0,369)\end{array}$ \\
\hline Háskólamenntun & $\begin{array}{c}, 422 \\
(0,331)\end{array}$ & $\begin{array}{l}, 616+ \\
(0,328)\end{array}$ & $\begin{array}{c}, 297 \\
(0,333)\end{array}$ \\
\hline Karlar (viðmið=konur) & $\begin{array}{l}, 446+ \\
(0,243)\end{array}$ & $\begin{array}{c}-0,26 \\
(0,245)\end{array}$ & $\begin{array}{c}-, 243 \\
(0,247)\end{array}$ \\
\hline $\begin{array}{l}\text { Höfuðborgarsvæði } \\
\text { (viðmið=landsbyggð) }\end{array}$ & $\begin{array}{c}-, 121 \\
(0,223)\end{array}$ & $\begin{array}{c}, 135 \\
(0,220)\end{array}$ & $\begin{array}{c}, 123 \\
(0,223)\end{array}$ \\
\hline $\begin{array}{l}\text { Æðstu embættismenn, sérfræðingar og } \\
\text { sérmenntað starfsfólk }\end{array}$ & Viðmið & & \\
\hline $\begin{array}{l}\text { Pjónustustörf, skrifstofu- og } \\
\text { afgreiðslufólk }\end{array}$ & $\begin{array}{c}-, 232 \\
(0,306)\end{array}$ & $\begin{array}{l}, 188 \\
(0,303)\end{array}$ & $\begin{array}{l}-, 227 \\
(0,307)\end{array}$ \\
\hline $\begin{array}{l}\text { Iðnaðarmenn, véla- og vélgæslufólk, } \\
\text { bændur og sjómenn }\end{array}$ & $\begin{array}{c}0,07 \\
(0,363)\end{array}$ & $\begin{array}{c}-, 123 \\
(0,364)\end{array}$ & $\begin{array}{c}-, 424 \\
(0,368)\end{array}$ \\
\hline Ósérhæft starfsfólk & $\begin{array}{c}, 187 \\
(0,477)\end{array}$ & $\begin{array}{c}-, 989 \\
(0,989)\end{array}$ & $\begin{array}{c}, 140 \\
(0,477)\end{array}$ \\
\hline Aldur & $\begin{array}{c}, 002 \\
(0,007)\end{array}$ & $\begin{array}{c}-, 008 \\
(0,007)\end{array}$ & $\begin{array}{c}-, 003 \\
(0,007)\end{array}$ \\
\hline $\begin{array}{l}\text { Vinna ætti að pví að bæta lífskjör } \\
\text { útlendinga á Íslandi }\end{array}$ & $\begin{array}{l}453^{* * *} \\
(0,084)\end{array}$ & $\begin{array}{l}, 533^{* * *} \\
(0,084)\end{array}$ & $\begin{array}{l}, 516^{* * *} \\
(0,085)\end{array}$ \\
\hline
\end{tabular}


Tafla 4. Telur pú að pað sé almennt gott eða slæmt fyrir efnahag landsins að fólk frá öðrum löndum flytjist til pess (1=slæmt, 10=gott), að pað auðgi eða grafi undan íslensku menningarlífi (1=grefur undan, 10=auðgar), að pað geri Ísland að verri eða betri stað að búa á ef innflytjendum fjölgar (1=verri, 10=betri)? Samanburður á milli 23 Evrópuríkja.

\begin{tabular}{|c|c|c|c|}
\hline & $\begin{array}{l}\text { Gott eða } \\
\text { slæmt fyrir } \\
\text { efnahag } \\
\text { Íslands }\end{array}$ & $\begin{array}{l}\text { Auðgar eða } \\
\text { grefur undan } \\
\text { íslensku } \\
\text { menningar- } \\
\text { lífi }\end{array}$ & $\begin{array}{c}\text { Gerir pað } \\
\text { Ísland að } \\
\text { betri eða } \\
\text { verri stað að } \\
\text { búa á }\end{array}$ \\
\hline Ísland 2008 & 5,9 & 6,3 & 6,0 \\
\hline Ísland 2005 & 6,0 & 6,8 & 6,5 \\
\hline \multicolumn{4}{|l|}{ Önnur Evrópuríki 2002: } \\
\hline Finnland & 6,8 & 7,3 & 6,2 \\
\hline Lúxemborg & 5,9 & 7,2 & 5,8 \\
\hline Svípjóð & 5,6 & 7,1 & 5,5 \\
\hline Sviss & 5,5 & 6,3 & 5,3 \\
\hline Pólland & 5,4 & 6,2 & 5,3 \\
\hline Pýskaland & 5,4 & 6,2 & 5,3 \\
\hline Holland & 5,3 & 6,0 & 5,2 \\
\hline Spánn & 5,3 & 5,8 & 4,8 \\
\hline Austurríki & 5,1 & 5,8 & 4,8 \\
\hline Belgía & 5,1 & 5,8 & 4,8 \\
\hline Noregur & 5,0 & 5,8 & 4,7 \\
\hline Danmörk & 5,0 & 5,8 & 4,7 \\
\hline Ísrael & 4,8 & 5,7 & 4,7 \\
\hline Írland & 4,8 & 5,6 & 4,5 \\
\hline Portúgal & 4,8 & 5,4 & 4,5 \\
\hline Ítalía & 4,6 & 5,3 & 4,5 \\
\hline Slóvenía & 4,5 & 5,2 & 4,5 \\
\hline Frakkland & 4,4 & 5,2 & 4,3 \\
\hline Bretland & 4,4 & 5,1 & 4,2 \\
\hline Ungverjaland & 4,3 & 5,1 & 4,0 \\
\hline Tékkland & 4,1 & 4,6 & 3,9 \\
\hline Grikkland & 3,6 & 3,6 & 3,4 \\
\hline Heildarmeðaltal Evrópuríkja 2002 & 5,0 & 5,8 & 4,8 \\
\hline
\end{tabular}


Í töflu 3 má sjá niðurstöður úr aðhvarfsgreiningu par sem fylgibreyturnar eru spurningarnar prjár um hugsanlegan ávinning pess fyrir íslenskt samfélag ef fólk frá öðrum löndum flytur til landsins og frumbreyturnar eru menntun, kyn, starf, aldur og afstaða til pess hvort pað skipti máli að bæta lífskjör útlendinga á Íslandi.

Í öllum premur tilfellum höfðu peir sem töldu pað skipta máli að lífskjör útlendinga yrðu bætt á Íslandi jákvæðari afstöðu gagnvart innflytjendum heldur en peir sem töldu pað skipta litlu máli. Pegar aðeins eru skoðaðar niðurstöður aðhvarfsgreiningar par sem spurt var um hvort að fjölgun innflytjenda geri Íslandi að betri eða verri stað að búa á voru konur frekar peirrar skoðunar en karlar að pað gerði Ísland að verri stað til að búa á, að teknu tilliti til menntunar, búsetu, starfs, aldurs og pess hvort fólk teldi pað skipta máli að lífskjör útlendinga yrðu bætt á Íslandi. Að lokum voru háskólamenntaðir frekar á peirri skoðun að innflytjendur auðgi íslenskt menningarlíf samanborið við pá sem eru með grunnskólamenntun, að teknu tilliti til kyns, búsetu, starfs, aldurs og afstöðu til pess hvort hversu miklu máli skiptir að bæta lífskjör útlendinga á Íslandi.

Í töflu 4 má sjá samanburð á meðaltölum í svörum við pessum premur spurningum á milli 22 Evrópuríkja og Ísraels úr ESS könnuninni. Aftur skipa Íslendingar sér í hóp jákvæðustu ríkjanna gagnvart innflytjendum, bæði árin 2005 og 2008, prátt fyrir pá breytingu í neikvæða átt sem hefur orðið á afstöðu Íslendinga á pessu priggja ára tímabili.

\subsection{Aðlögun innflytjenda}

Í pessum hluta er fjallað um svör við peirri spurningu hvort pað sé betra fyrir pjóðfélagið í heild að innflytjendur viðhaldi sínum sérstöku siðum og hefðum eða hvort pað sé betra að peir geri pað ekki heldur tileinki sér siði og hefðir pess lands sem peir flytja til. Í fyrri staðhæfingunni, pað er að pað sé betra að peir viðhaldi sínum sérstöku siðum og hefðum, parf ekki að felast að peir taki ekki upp hefðir og siði pess lands sem peir flytja til. Samt sem áður er ekki hægt að útiloka pað að svarendur hafi lagt pann skilning í fyrri staðhæfinguna að ef innflytjendur viðhalda sínum siðum og venjum útiloki pað að peir taki einnig upp hefðir og siði pess lands sem peir flytja til. Pegar pessum tveimur staðhæfingum er stillt upp saman gæti litið svo út að pær væru andstæður og útiloki hvor aðra. Pó var ákveðið að hafa spurninguna óbreytta par sem hún var lögð fyrir í lífsgildakönnun á Íslandi og í 33 öðrum ríkjum árið 1999 og áhugi var á pví að bera saman svörin sem fengust árið 2008 við eldri svör.

Árið 2008 sögðu um 80\% svarenda pað betra fyrir pjóðfélagið í heild að innflytjendur viðhaldi ekki sínum sérstöku siðum og hefðum heldur tileinki sér siði pess lands sem peir flytja til á móti tæpum 20\% sem töldu pað betra að innflytjendur viðhaldi sínum sérstöku siðum og hefðum (mynd 4). Árið 1999 töldu hlutfallslega fleiri að pað væri betra ef innflytjendur viðhéldu siðum sínum og venjum eða 27,2\% á móti tæpum 20\% árið 2008. 


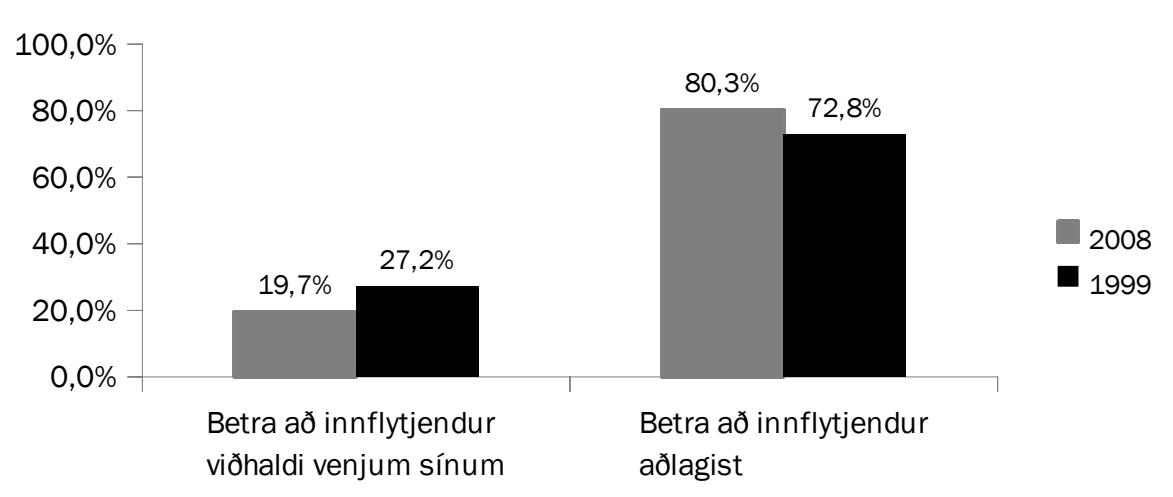

Mynd 4. Er betra að innflytjendur viðhaldi sínum sérstöku siðum eða að peir geri pað ekki heldur tileinki sér siði pess lands sem peir flytja til? Samanburður á milli 1999 og 2008.

Í aðhvarfsgreiningunni í töflu 5 voru peir viðmiðunarhópur sem töldu að innflytjendur ættu ekki að viðhalda sínum eigin siðum og venjum heldur taka upp siði og venjur pess lands sem peir flytja til par sem svörin eru á nafnkvarða. Peir sem búa á höfuðborgarsvæðinu voru frekar á peirri skoðun að innflytjendur ættu að viðhalda eigin siðum og venjum samanborið við pá sem búa utan höfuðborgarsvæðisins. Peir sem störfuðu í ósérhæfðum verkamannastörfum töldu frekar að innflytjendur ættu að tileinka sér siði pess lands sem peir flyttu til, samanborið við pá sem starfa sem æðstu embættismenn, sérfræðingar og sérmenntað starfsfólk. Að lokum voru peir sem töldu pað skipta máli að bæta lífskjör útlendinga á Íslandi oftar peirrar skoðunar að innflytjendur ættu að viðhalda sínum sérstöku siðum og hefðum samanborið við pá sem töldu pað skipta litlu máli í pví að bæta lífskjör peirra.

Pegar svör við spurningunni um pað hvort betra sé fyrir pjóðfélagið í heild að innflytjendur viðhaldi siðum sínum eða ekki eru borin saman við svör annarra ríkja í lífsgildakönnunum árið 1999 má sjá að árið 2008 skipa Íslendingar sér í hóp peirra sem vilja síst að innflytjendur viðhaldi siðum sínum og hefur peim fækkað hlutfallslega síðan könnunin var lögð fyrir á Íslandi árið 1999 (mynd 5). Tæplega 20\% Íslendinga svöruðu árið 2008 að innflytjendur ættu að viðhalda siðum sínum en árið 1999 voru pað rúmlega 27\% sem völdu pann svarmöguleika. Árið 1999 voru Austurríki og Austur-Pýskaland einu ríkin par sem petta hlutfall var lægra en á Íslandi árið 2008, eða 17,9\% í báðum ríkjum. 
Tafla 5. Er betra að innflytjendur viðhaldi sínum sérstöku siðum eða að peir geri pað ekki heldur tileinki sér siði pess lands sem peir flytja til? Greint eftir menntun, kyni, búsetu, starfi, aldri og poí hvort vinna ætti að pví að bæta lífskjör útlendinga á Íslandi. 2008.

\begin{tabular}{lc}
\hline & $\begin{array}{c}\text { B } \\
\text { (Staðalvilla) }\end{array}$ \\
\hline Fasti & 1,626 \\
\hline Grunnskólamenntun & Viðmið \\
Bókleg framhaldsskólamenntun &, 228 \\
& $(0,385)$ \\
Iðnmenntun &,- 537 \\
& $(0,470)$ \\
Háskólamenntun &,- 452 \\
& $(0,387)$ \\
\hline Karlar (viðmið=konur) &,- 079 \\
\hline Höfuðborgarsvæði & $(0,300)$ \\
(viðmið=landsbyggð) &,$- 771 *$ \\
\hline Æðstu embættismenn, sérfræðingar & $(0,261)$ \\
og sérmenntað starfsfólk & Viðmið \\
Pjónustustörf, skrifstofu- og &,- 473 \\
afgreiðslufólk & $(0,364)$ \\
Iðnaðarmenn, véla- og vélgæslufólk, &,- 488 \\
bændur og sjómenn & $(0,439)$ \\
Ósérhæft starfsfólk & $-1,340 *$ \\
\hline Aldur & $(0,646)$ \\
\hline Vinna ætti að pví að bæta lífskjör &, 001 \\
útlendinga á Íslandi & $(0,009)$ \\
\hline &, $325 *$ \\
& $(0,113)$ \\
\hline
\end{tabular}




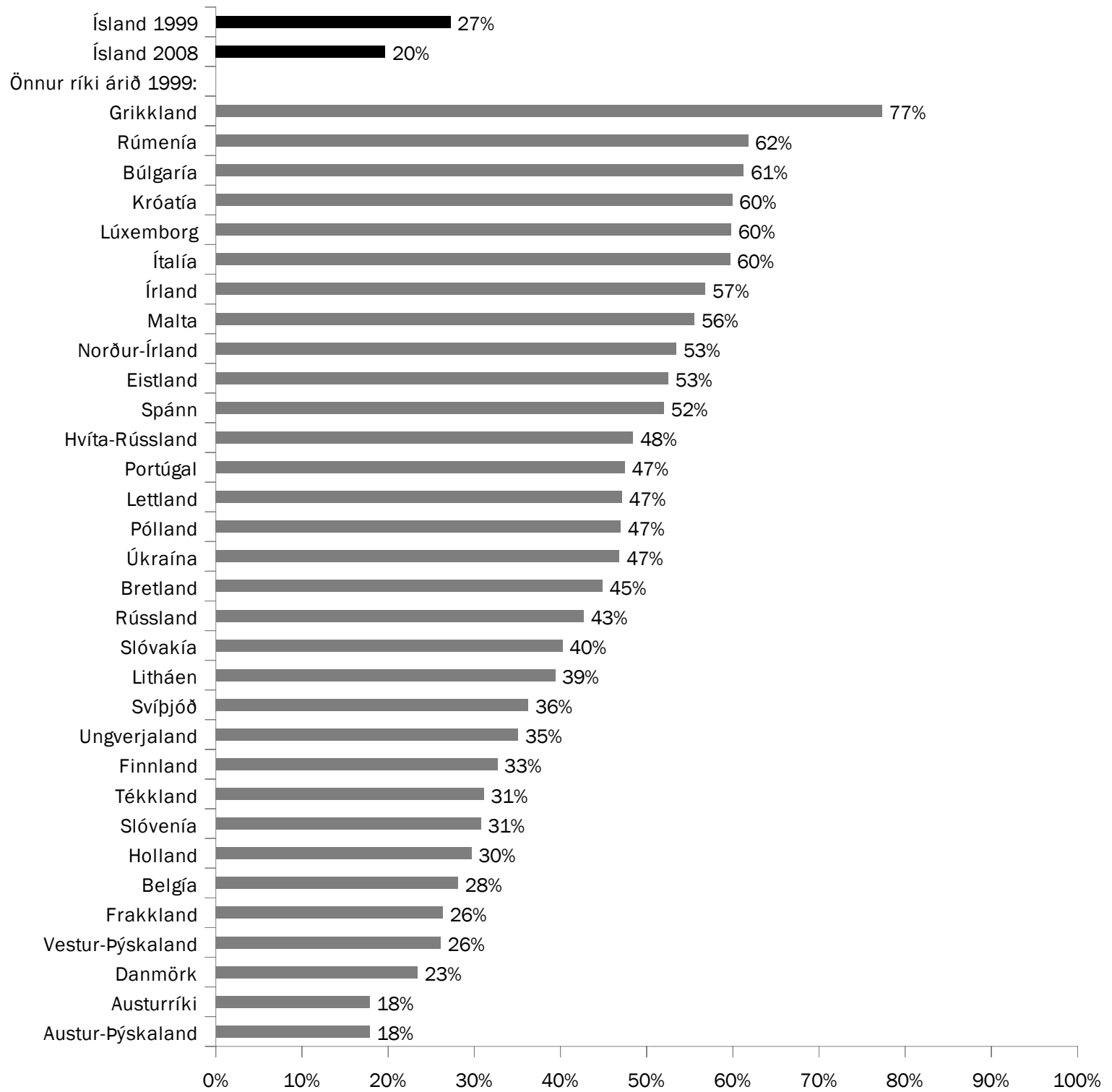

Mynd 5. Deir sem svara að pað sé betra að innflytjendur viðhaldi siðum sínum og venjum. Samanburður á milli 33 ríkja. 


\subsection{Innflytjendur á vinnumarkaði}

Fjórar staðhæfingar voru settar fram um viðhorf til innflytjenda á íslenskum vinnumarkaði og voru svarendur beðnir um að segja hvort peir væru peim sammála eða ósammála. Fyrsta staðhæfingin var á pá leið að atvinnurekendur ættu frekar að ráða Íslendinga í vinnu heldur en aðra pegar atvinna væri af skornum skammti. Næsta staðhæfing fól í sér að innflytjendur væru í samkeppni við Íslendinga um störf á íslenskum vinnumarkaði. Síðustu tvær staðhæfingarnar voru um laun; sú fyrri um að fjölgun innflytjenda og farandverkamanna á Íslandi lækkaði almennt meðallaun á Íslandi og sú síðari að fjölgun peirra lækkaði meðallaun í peim atvinnugreinum sem innflytjendur og farandverkamenn starfa helst í.

Tafla 6. Degar atvinna er af skornum skammti eiga atvinnurekendur að ráda Íslendinga í vinnu frekar en aðra. 2008.

\begin{tabular}{lccc}
\hline & Fjöldi & Hlutfall svara & Hlutfall allra \\
\hline Mjög sammála & 132 & $24,8 \%$ & $23,5 \%$ \\
Frekar sammála & 91 & $17,1 \%$ & $16,2 \%$ \\
Hvorki sammála né ósammála & 48 & $9,0 \%$ & $8,5 \%$ \\
Frekar ósammála & 146 & $27,4 \%$ & $26,0 \%$ \\
Mjög ósammála & 115 & $21,6 \%$ & $20,5 \%$ \\
\hline Samtals & 532 & $100 \%$ & \\
\hline Veit ekki & 18 & & $3,2 \%$ \\
Neitar að svara & 12 & & $2,1 \%$ \\
\hline Samtals & 562 & & $100 \%$ \\
\hline
\end{tabular}

Tæplega fjórðungur peirra sem tóku afstöðu var mjög sammála pví að atvinnurekendur ættu að ráða Íslendinga í vinnu frekar en aðra pegar atvinna væri af skornum skammti (tafla 6). Samtals var tæpur helmingur svarenda frekar eða mjög ósammála staðhæfingunni á móti tæpum $42 \%$ sem voru henni mjög eða frekar sammála.

Pegar svarendur voru spurðir hvort peir væru sammála eða ósammála peirri staðhæfingu að innflytjendur væru í samkeppni við Íslendinga um störf á íslenskum vinnumarkaði voru $22,2 \%$ pví mjög sammála en 12,1\% pví mjög ósammála (tafla 7). Samtals voru 56,3\% staðhæfingunni mjög eða frekar sammála á móti 35,1\% sem voru henni mjög eða frekar ósammála en 8,6\% svöruðu hvorki né. 
Tafla 7. Innflytjendur eru í samkeppni við Íslendinga um störf á vinnumarkaði hér á landi. 2008.

\begin{tabular}{lccc}
\hline & Fjöldi & Hlutfall svara & Hlutfall allra \\
\hline Mjög sammála & 116 & $22,2 \%$ & $20,6 \%$ \\
Frekar sammála & 178 & $34,1 \%$ & $31,7 \%$ \\
Hvorki sammála né ósammála & 45 & $8,6 \%$ & $8,0 \%$ \\
Frekar ósammála & 120 & $23,0 \%$ & $21,4 \%$ \\
Mjög ósammála & 63 & $12,1 \%$ & $11,2 \%$ \\
\hline Samtals & 522 & $100 \%$ & \\
\hline Veit ekki & 25 & & $4,4 \%$ \\
Neitar að svara & 15 & & $2,7 \%$ \\
\hline Samtals & 562 & & $100 \%$ \\
\hline
\end{tabular}

Í töflu 8 má sjá að munur er á afstöðu fólks eftir starfi til pess hvort Íslendingar eigi að ganga fyrir í störf pegar atvinna er af skornum skammti. Peir sem vinna ósérhæfð verkamannastörf eru frekar hlynntir pví að Íslendingar gangi fyrir í störf samanborið við æðstu stjórnendur og embættismenn, að teknu tilliti til menntunar, kyns, búsetu og afstöðu til pess hvort pað skipti máli að bæta lífskjör útlendinga á Íslandi. peir sem töldu að pað skipti máli að bæta lífskjör útlendinga á Íslandi voru frekar peirrar skoðunar að Íslendingar ættu ekki að ganga fyrir í störf og að útlendingar væru ekki í samkeppni við Íslendinga um atvinnu. Ef greint var eftir kyni töldu karlar frekar að innflytjendur væru í samkeppni við Íslendinga um störf á vinnumarkaði samanborið við konur.

Að lokum voru tvær spurningar lagðar fyrir pátttakendurpar sem fyrst var spurt um hversu sammála eða ósammála fólk væri peirri staðhæfingu að fjölgun innflytjenda eða farandverkamanna á Íslandi lækkaði meðallaun almennt á landinu og pví hvort fjölgunin lækkaði meðallaun í peim atvinnugreinum sem innflytjendur starfa helst í.

Fjórðungur svarenda var mjög sammála pví að fjölgun innflytjenda og farandverkamanna á Íslandi lækki almennt meðallaun (tafla 9). Samtals voru 63,6\% mjög eða frekar sammála staðhæfingunni á móti tæpum 30\% sem voru mjög eða frekar ósammála en 6,5\% sögðust hvorki vera sammála né ósammála. Aðeins fleiri telja að fjölgun innflytjenda á íslenskum vinnumarkaði leiði til pess að meðallaun í peim atvinnugreinum sem peir starfa í á Íslandi lækki heldur en pegar spurt var um hvort meðallaun lækki almennt (tafla 10). 
Tafla 8. Pegar atvinna er af skornum skammti eiga atvinnurekendur að ráða Íslendinga í vinnu frekar en aðra og innflytjendur eru í samkeppni við Íslendinga um störf ( $1=$ mjög sammála, 2=frekar sammála, 3=hvorki sammála né ósammála, 4=frekar ósammála, 5=mjög ósammála). Greint eftir menntun, kyni, búsetu, starfi, aldri og poí hvort vinna ætti að pví að bæta lífskjör útlendinga á Íslandi. 2008.

\begin{tabular}{|c|c|c|}
\hline & $\begin{array}{l}\text { Pegar atvinna er af } \\
\text { skornum skammti } \\
\text { eiga atvinnu- } \\
\text { rekendur að ráða } \\
\text { Íslendinga í vinnu } \\
\text { frekar en aðra }\end{array}$ & $\begin{array}{l}\text { Innflytjendur eru í } \\
\text { samkeppni við } \\
\text { Íslendinga um störf } \\
\text { á vinnumarkaði hér } \\
\text { á landi }\end{array}$ \\
\hline & $\begin{array}{c}\text { B } \\
\text { (Staðalvilla) }\end{array}$ & $\begin{array}{c}\text { B } \\
(\text { Staðalvilla) }\end{array}$ \\
\hline Fasti & 1,787 & 2,213 \\
\hline Grunnskólamenntun & Viðmið & \\
\hline Bókleg framhaldsskólamenntun & $\begin{array}{c}, 205 \\
(0,217)\end{array}$ & $\begin{array}{c}, 227 \\
(0,199)\end{array}$ \\
\hline Iðnmenntun & $\begin{array}{c}-, 252 \\
(0,244)\end{array}$ & $\begin{array}{c}-, 072 \\
(0,226)\end{array}$ \\
\hline Háskólamenntun & $\begin{array}{c}, 171 \\
(0,216)\end{array}$ & $\begin{array}{c}-, 028 \\
(0,200)\end{array}$ \\
\hline Karlar (viðmið=konur) & $\begin{array}{c}, 325 \\
(0,161)\end{array}$ & $\begin{array}{l}-, 349 * \\
(0,149)\end{array}$ \\
\hline $\begin{array}{l}\text { Höfuðborgarsvæði } \\
\text { (viðmið=landsbyggð) }\end{array}$ & $\begin{array}{c}, 240 \\
(0,146)\end{array}$ & $\begin{array}{c}-, 168 \\
(0,135) \\
\end{array}$ \\
\hline $\begin{array}{l}\text { Æðstu embættismenn, sérfræðingar og } \\
\text { sérmenntað starfsfólk }\end{array}$ & Viðmið & \\
\hline $\begin{array}{l}\text { Pjónustustörf, skrifstofu- og } \\
\text { afgreiðslufólk }\end{array}$ & $\begin{array}{c}, 077 \\
(0,199)\end{array}$ & $\begin{array}{c}-, 272 \\
(0,185)\end{array}$ \\
\hline $\begin{array}{l}\text { Iðnaðarmenn, véla- og vélgæslufólk, } \\
\text { bændur og sjómenn } \\
\text { Ósérhæft starfsfólk }\end{array}$ & $\begin{array}{l}-, 145 \\
(0,240) \\
-, 657^{*} \\
(0,316)\end{array}$ & $\begin{array}{c}-, 181 \\
(0,221) \\
, 169 \\
(0,294)\end{array}$ \\
\hline Aldur & $\begin{array}{l}-, 005 \\
(0,005)\end{array}$ & $\begin{array}{c}, 005 \\
(0,005)\end{array}$ \\
\hline $\begin{array}{l}\text { Vinna ætti að pví að bæta lífskjör } \\
\text { útlendinga á Íslandi }\end{array}$ & $\begin{array}{l}, 293^{* * *} \\
(0,056)\end{array}$ & $\begin{array}{l}1,141 * * \\
(0,051)\end{array}$ \\
\hline
\end{tabular}


Tafla 9. Fjölgun innflytjenda eða farandverkamanna á Íslandi lækka almennt meðallaun á Íslandi. 2008.

\begin{tabular}{lccc}
\hline & Fjöldi & Hlutfall svara & Hlutfall allra \\
\hline Mjög sammála & 131 & $25,9 \%$ & $23,3 \%$ \\
Frekar sammála & 190 & $37,6 \%$ & $33,8 \%$ \\
Hvorki sammála né ósammála & 33 & $6,5 \%$ & $5,9 \%$ \\
Frekar ósammála & 112 & $22,2 \%$ & $19,9 \%$ \\
Mjög ósammála & 39 & $7,7 \%$ & $6,9 \%$ \\
\hline Samtals & 505 & $100 \%$ & \\
\hline Veit ekki & 46 & & $8,2 \%$ \\
Neitar að svara & 11 & & $2,0 \%$ \\
\hline Samtals & 562 & & $100 \%$ \\
\hline
\end{tabular}

Tafla 10. Fjölgun innflytjenda eða farandverkamanna sem koma erlendis frá til að vinna á Íslandi verður til pess að meðallaun lækka í peim atvinnugreinum sem peir starfa í á Íslandi. 2008.

\begin{tabular}{lccc}
\hline & Fjöldi & Hlutfall svara & Hlutfall allra \\
\hline Mjög sammála & 144 & $28,6 \%$ & $25,6 \%$ \\
Frekar sammála & 200 & $39,8 \%$ & $35,6 \%$ \\
Hvorki sammála né ósammála & 38 & $7,6 \%$ & $6,8 \%$ \\
Frekar ósammála & 84 & $16,7 \%$ & $14,9 \%$ \\
Mjög ósammála & 37 & $7,4 \%$ & $6,6 \%$ \\
\hline Samtals & 503 & $100 \%$ & \\
\hline Veit ekki & 45 & & $8,0 \%$ \\
Neitar að svara & 14 & & $2,5 \%$ \\
\hline Samtals & 562 & & $100 \%$ \\
\hline
\end{tabular}

\subsection{Samandregnar niðurstöður: Samanburður á milli ára á Íslandi og við önnur ríki}

Í peim gögnum par sem til er samanburður á milli ára í spurningum sem lagðar eru fyrir á Íslandi og spurningum sem hafa verið lagðar fyrir í öðrum ríkjum má greina tvennt. Annars vegar virðist sem Íslendingar séu almennt jákvæðari í afstöðu sinni til innflytjenda samanborið við önnur Evrópuríki og Ísrael en hins vegar virðist heldur hafa dregið úr pessari jákvæðni á Íslandi á milli áranna 2005 og 2008. Í öllum premur spurningunum sem lagðar voru fyrir á Íslandi árin 2005 og 2008 um pað hversu mörgum eða fáum innflytjendum ætti að hleypa til landsins hefur orðið hlutfallsleg fækkun meðal peirra sem segja að hleypa eigi mörgum til landsins. Á sama tíma eru 
Íslendingar í hópi peirra ríkja par sem hlutfallslega flestir segjast vilja hleypa mörgum inn í landið samanborið við svör úr sömu fjórum spurningum sem lagðar voru fyrir í 22 öðrum ríkjum árið 2002. Ekki er hægt að útiloka pað að sama próun hafi orðið á viðhorfum almennings í pessum 22 ríkjum frá 2002 til ársins 2008, pað er að segja að dregið hafi úr vilja fólks til að hleypa fleiri innflytjendum inn í landið. Рað er áhugavert að velta pví fyrir sér hvort viðhorf Íslendinga hafi breyst vegna aukins fjölda innflytjenda frá árinu 2005 en eins og kemur fram í inngangi hefur innflytjendum fjölgað verulega á Íslandi frá síðustu aldamótum.

Pegar spurt var um hvort pað væri betra eða verra fyrir efnahag Íslands að fólk frá öðrum löndum flyttist hingað, hvort pað auðgaði eða græfi undan íslensku menningarlífi og hvort pað gerði Ísland að betri eða verri stað að búa á töldu færri árið 2008 að pað gerði Ísland að betri stað til að búa á og að pað auðgaði íslenskt menningarlíf samanborið við 2005. Ekki virtist hafa orðið breyting á afstöðu fólks til pess hvort pað væri gott eða slæmt fyrir efnahag Íslands að fólk frá öðrum löndum flyttist til landsins og er pað áhugavert í ljósi umræðu um efnahagslegan ávinning af komu innflytjenda. Рað vekur upp pá spurningu hvort Íslendingar hafi enn séð efnahagslegan hag af komu innflytjenda til landsins árið 2008 prátt fyrir að sú afstaða hafi orðið heldur neikvæðari frá árinu 2005. Par sem könnunin er framkvæmd skömmu áđur en efnahagskreppa skall á af fullum punga á haustmánuðum 2008 er hugsanlegt að pessi afstaða hafi breyst og er pað verðugt rannsóknarefni.

Pegar svör við pessum premur spurningum um hvort pað sé betra eða verra fyrir efnahag Íslands, hvort pað auðgi eða grafi undan íslensku menningarlífi og hvort pað geri Ísland að betri eða verri stað að búa á eru borin saman við svör í 22 öðrum ríkjum árið 2002 má sjá sama mynstur og í spurningunum um pað hversu mörgum innflytjendum ætti að hleypa til landsins. Prátt fyrir að afstaða Íslendinga virðist hafa orðið að sumu leyti neikvæðari voru peir árið 2008 enn í hópi peirra sem eru jákvæðastir í garð innflytjenda samanborið við hin ríkin.

Pegar spurt var um hvort innflytjendur ættu að viðhalda eigin siðum og venjum eða ekki virtust flestir vera peirrar skoðunar að pað sé betra fyrir pjóðfélagið í heild að innflytjendur viðhaldi ekki sínum sérstöku siðum og hefðum heldur tileinki sér siði pess lands sem peir flytja til. Hér hefur pegar verið bent á að síðari staðhæfingin felur ekki í sér útilokun á pví að innflytjendur tileinki sér líka siði pess lands sem peir flytja til en ekki er hægt að útiloka að svarendur hafi skilið staðhæfingarnar sem andstæður sem útiloki hvor aðra. Draga má pá ályktun af svörum pátttakenda að ef valið stendur á milli pess að halda eigin siðum og hefðum, eða láta af peim og taka upp siði og hefðir pess lands sem flutt er til, pá séu fleiri sem telja að síðari kostinn sé betri fyrir pjóðfélagið í heild. Petta er áhugavert í ljósi umræðunnar um fjölmenningu og vekur upp pá spurningu hvort pað sé ríkjandi hugsunarháttur meðal Íslendinga að innflytjendur aðlagist menningu peirra fyrrnefndu í stað fjölmenningar par sem innflytjendur halda eigin siðum og venjum samhliða pví að taka pátt í nýju samfélagi. Petta getur bent til pess að Íslendingar séu fastir í hugmyndum sem Unnur 
Dís Skaptadóttir (2004) varar við, pað er að menning sé óbreytanlegur fasti í peirri merkingu að aðeins sé ein menning í landinu sem breytist lítið og að aðkomufólk eigi að taka hana gagnrýnislaust upp. Рað sýnir sig í samanburði við svör við sömu spurningu í 32 öðrum ríkjum árið 1999 að Íslendingar eru síst hlynntir pví að innflytjendur haldi eigin siðum og venjum og skipa peir sér pví í hóp með ríkjum eins og Danmörku, en par hefur myndast mikil togstreita á milli innflytjenda og heimamanna (Eiríkur Bergmann Einarsson, 2007).

\subsection{Innflytjendur á vinnumarkaði}

Um 40\% svarenda voru pví sammála að pegar atvinna er af skornum skammti ættu atvinnurekendur frekar að ráða Íslendingar heldur en útlendinga í vinnu. Petta er áhugavert í ljósi peirra fjöldauppsagna sem fjölmörg fyrirtæki hafa gripið til frá hausti 2008 og ekki er útséð með á árinu 2009. Petta getur bent til pess að pegar atvinnuleysi eykst geti pað alið á óánægju í garð útlendinga meðal peirra sem líta svo á að peir taki atvinnu frá heimamönnum. Pessi óánægja getur birst bæði sem bein óánægja með að innflytjendur eru í störfum sem fólk eða einstaklingar myndu persónulega vilja sinna eða að peir séu í störfum par sem fólk telur að aðrir heimamenn eða innfæddir gætu sinnt. Í sama anda telur ríflega helmingur svarenda að innflytjendur séu í samkeppni við Íslendinga um störf á íslenskum vinnumarkaði. Pessa spurningu má gagnrýna fyrir pað fólk getur svarað henni með pað í huga að almennt sé fólk í samkeppni um störf á vinnumarkaði burtséð frá pví hvort pað séu innfæddir eða innflytjendur. Á móti kemur að spurningin felur í sér beina skírskotun til innflytjenda andspænis Íslendingum og með pví er reynt að greina hvort svarendur telji að innflytjendur taki störf frá heimamönnum. Раð аð rúmlega helmingur telji svo vera getur bent til pess að hópur Íslendinga líti á innflytjendur sem sérstakan hóp sem aðgreini sig frá innfæddum en pó er pörf á frekari rannsóknum til að geta fullyrt frekar um pað.

Meirihluti svarenda var sammála pví að fjölgun innflytjenda og erlendra farandverkamanna lækki bæði meðallaun á Íslandi almennt og meðallaun í peim atvinnugreinum sem innflytjendur og farandverkamenn starfa í. Ef svör við pessarri spurningu eru skoðuð í samhengi við svör við spurningunni um hvort atvinnurekendur ættu frekar að ráđa Íslendinga heldur en útlendinga í vinnu, pegar atvinna er af skornum skammti, má leiða líkur að pví að óánægja í garð útlendinga geti ekki einungis skapast vegna pess að peir taki störf frá heimamönnum heldur einnig vegna pess að talið er að peir fái störfin vegna pess að peir fái minna greitt fyrir vinnu sína. Sú trú að innflytjendur lækki meðallaun getur verið tilkomin vegna pess að svarendur telji að innflytjendur sætti sig við lægri laun og par af leiðandi verði peir eftirsóttara vinnuafl og taki störf frá heimamönnum. Petta tvennt getur svo enn frekar alið á óánægju í garð innflytjenda, burtséð frá pví hvort pað sé á rökum reist að innflytjendur piggi almennt lægri laun en heimamenn. 


\subsection{Menntun, kyn, búseta, starf og aldur}

Almennt má segja að pegar svör við viðhorfum íslenskra ríkisborgara eru greind eftir menntun, kyni, búsetu, starfi, aldri og pess hvort pað skipti máli að bæta lífskjör útlendinga á Íslandi, má sjá að peir sem telja pað síðastnefnda skipta máli höfðu í öllum tilfellum jákvæðari afstöðu til innflytjenda í samanburði við pá sem telja að pað skipti litlu máli að bæta lífskjör peirra. Pessi niðurstaða er í samræmi við niðurstöður Ooschot og Uunk (2007) um að peir sem aðhyllast gildi um jöfnuð í samfélaginu hafa jákvæðari afstöðu til innflytjenda og líta svo á að peir eigi að njóta sömu réttinda og aðrir samfélagspegnar.

Að sama skapi kom fram munur á afstöðu fólks eftir menntun par sem peir sem eru með háskólamenntun voru frekar á peirri skoðun að hleypa ætti mörgum innflytjendum til landsins og að innflytjendur auðgi íslenskt menningarlíf samanborið við pá sem eru eingöngu með grunnskólamenntun. Jákvæðari afstaða háskólamenntaðra gagnvart innflytjendum sem endurspeglast í pessum svörum getur bent til pess að peir aðhyllist frekar hugmyndir um fjölmenningu par sem litið sé svo á að innflytjendur auðgi menningarlíf á Íslandi og að peir telji að Íslandi sé ekki ógnað með fjölgun innflytjenda. Frekari rannsókna parf við til að svara pví með skýrari hætti hvort fólk með háskólamenntun aðhyllist frekar hugmyndir um fjölmenningu samanborið við pá sem hafa minni menntun.

Jafnframt kom fram munur eftir starfi pegar spurt var um hvort innflytjendur ættu að halda í sína eigin sérstöku siði og hefðir eða taka upp siði pess lands sem peir flytja til og hvort Íslendingar ættu að ganga fyrir í vinnu pegar atvinna væri af skornum skammti. Peir sem eru í ósérhæfðum verkamannastörfum voru frekar hlynntir pví að innflytjendur ættu að taka upp siði pess lands sem peir flytja til og að Íslendingar ættu að ganga fyrir í vinnu. Petta er í samræmi við niðurstöður van Oorschot og Uunk (2007) um að peir sem eru verr staddir efnahags- og félagslega hafi neikvæðari ímynd af innflytjendum og upplifi pá frekar sem samkeppni á vinnumarkaði par sem innflytjendur taki störf frá innfæddum. Jafnframt var munur á afstöðu Íslendinga eftir búsetu par sem peir sem búa utan höfuðborgarsvæðisins töldu frekar að innflytjendur ættu að láta af eigin siðum og venjum og taka upp siði pess lands sem peir flytjast til samanborið við íbúa á höfuðborgarsvæðinu.

Pegar afstaða Íslendinga til innflytjenda er skoðuð eftir kyni töldu karlar frekar en konur að fjölgun innflytjenda hefði góð áhrif á efnahag Íslands og að sama skapi voru peir frekar peirrar skoðunar að innflytjendur væru í samkeppni við Íslendinga um störf á íslenskum vinnumarkaði. Pað kann að virðast pversögn fólgin í pví að karlar telji pað almennt vera gott fyrir íslenskan efnahag að innflytjendur komi til landsins og keppi við Íslendinga um störf. Petta parf pó ekki að vera pversögn par sem karlmenn geta talið pað almennt gott fyrir efnahaginn að hingað komi innflytjendur en á sama tíma talið að fólk á vinnumarkaði, bæði innflytjendur og Íslendingar, séu í samkeppni um störf sín á milli. Ekki kom fram munur eftir aldri í neinum af peim spurningum sem fjallað er um í pessari grein. 


\section{Lokaord}

Pað er athyglisvert að Íslendingar eru almennt jákvæðir gagnvart innflytjendum í samanburði við önnur ríki en á sama tíma og innflytjendum hefur fjölgað á Íslandi hefur sú afstaða orðið neikvæðari. Pví vaknar sú spurning hvort Íslendingar líti almennt svo á að svo lengi sem pað sé efnahagslegur ávinningur af innflytjendum sé í lagi að peir komi en að peir hafi samt sem áður tilhneigingu til að líta svo á að innflytjendur séu í samkeppni um störf, lækki almennt meðallaun, grafi undan menningarlífi og geri Ísland að verri stað til að búa á og ættu pess vegna að hafa sig af landi brott pegar atvinnuleysi eykst. Ef pað rétt má í ljósi efnahagskreppunnar sem skall á á Íslandi haustið 2008 leiða líkur að pví að innfæddir upplifi innflytjendur með enn neikvæðari hætti en áður par sem skortur er á atvinnu, sérstaklega í ljósi pess að pað hefur sýnt sig að innflytjendur flytjast ekki af landi brott í stórum stíl. Ef petta reyndist rétt gætu verið að ganga í garð tímar sem geta markað spor í afstöðu og hegðun Íslendinga gagnvart innflytjendum til langs tíma. Раð er að segja, ef pað er rétt að atvinnuleysi og kreppa geti alið á óánægju í garð innflytjenda gætum við séð fram á aukna neikvæðni og jafnvel fordóma í garð innflytjenda á Íslandi með peim vandamálum sem pví geta fylgt í samskiptum á milli Íslendinga og innflytjenda. Раð er pví parft verkefni að slá ekki slöku við í rannsóknum á viðhorfum til innflytjenda á Íslandi, aðbúnaði peirra og samskiptum við innfædda.

\section{Um höfundinn}

Eva Heiða Önnudóttir er aðjúnkt við félagsvísindadeild Háskólans á Bifröst og sérfræðingur á Rannsóknamiðstöð Háskólans á Bifröst. Netfang: evaheida@bifrost.is. Verkefnið hlaut styrk úr Próunarsjóði innflytjendamála á vegum félags- og tryggingamálaráđuneytis Íslands og frá Starfsgreinasambandinu.

\section{Heimildaskrá}

Ari Kl. Jónsson (2008). A critical analysis: the Icelandic immigration control policy. Óbirt MSc ritgerð. University of Bristol.

Capacent (2006). Ísland sem fjölmenningarsamfélag (frétt á vefsíðu Capacent, 2. nóvember 2006). Sótt 13. nóvember 2009 frá www.capacent.is/?PageID=762\&NewsID=239.

Castles, S., og Miller, M.J. (2003). The age of migration: international population movements in the modern world (3. útgáfa). Basingstoke: Palgrave MacMillan.

Dølvik, J.E. og Eldring, L. (2008). Mobility of labour from new EU states to the Nordic region: development trends and consequences. Nordic Council of Ministers publication 2008:537.

ECRI - European Commission against Racism and Intolerance (2007). Third report on Iceland, adopted on 30 June 2006. Strasbourg: Council of Europe.

Eiríkur Bergmann Einarsson (2007). Opið land: Ísland i samfélagi pjóðanna. Reykjavík: Skrudda. European Social Survey (e.d.). ESS Round 2 - 2004. Vefslóð: www.europeansocialsurvey.org. 
Félags- og tryggingamálaráđuneyti Íslands (2009). Helstu niðurstöður könnunar á viðhorfum til mismunar á Íslandi sem framkvæmd var í apríl 2009. Sótt 13. nóvember 2009 af www.felagsmalaraduneyti.is/media/09FrettatengtFEL09/09062009Helstu_nidurstodur_ vidhorfakonnunar_um_mismunun2.pdf.

Félags- og tryggingamálaráđuneyti Íslands (2007). Stefna ríkisstjórnarinnar um aðlögun innflytjenda. Janúar 2007. Slóð: http://www.felagsmalaraduneyti.is/media/acrobatskjol/Stefna_um_adlogun_innflytjenda.pdf.

Friðrik H. Jónsson (2003). Afstaða Íslendinga til útlendinga. Í Friðrik H. Jónsson (ritstjóri), Rannsóknir i félagsvísindum IV: Félagsvísindadeild (bls. 495-504). Reykjavík: Háskólaútgáfan.

Hagstofa Íslands (2009a). Búferlaflutningar milli landa eftir kyni, löndum og ríkisfangi 19862008. Sótt 16. nóvember 2009 af www.hagstofa.is.

Hagstofa Íslands (2009b). Innflytjendur og einstaklingar með erlendan bakgrunn 1996-2008. Hagtídindi, 94, 4 (20 janúar 2009).

Hagstofa Íslands (2009c). ÍSTARF95. Íslensk starfaflokkun með skýringum og dæmum. (2.útgáfa.) Reykjavík: Hagstofa Íslands.

Hagstofa Íslands (2009d). Ríkisfang, fæðingarland og uppruni íbúa. Sótt 29. júní 2009 af www.hagstofa.is.

Hallfríður Pórarinsdóttir, Sólveig H. Georgsdóttir og Berglind L. Hafsteinsdóttir (2009). Staða innflytjenda á erfiðleikatímum - raddir og viðhorf. Reykjavík: MIRRA - Miðstöð innflytjendarannsókna ReykjavíkurAkademíunni. Vefslóð: www.mirra.is/Stada_innflytjenda_a_erfidleikatimum.pdf.

Heiður Hrund Jónsdóttir, Hildur Svavarsdóttir, Kristín Erla Harðardóttir og Friðrik H. Jónsson (2004). Viðhorf innflytjenda á Vestfjörðum og Austurlandi. Reykjavík: Félagsvísindastofnun Háskóla Íslands.

Hilda Jana Gísladóttir og Jóhann Ásmundsson (2007). Könnun á stöðu innflytjenda á Norðurlandi. Skýrsla unnin fyrir Rauða kross Íslands, Akureyri. Sótt af vefsíðu www.redcross.is.

Kristín Loftsdóttir (2004). „Ég er ekki með kynpáttafordóma en ...“: Hugtakið kynpáttur og íslenskt samfélag. Í Úlfar Hauksson (ritstjóri), Rannsóknir i félagsvísindum V: Félagsvísindadeild (bls. 575-584). Reykjavík: Háskólaútgáfan.

Mahnig, H. (2005). The politics of minority-majority relations: how immigrant policies developed in Paris, Berlin and Zurich. Í Penninx, R., o.fl.. (ritstjórar), Citizenship in European cities: immigrants, local politics and integration policies (2.prentun, bls. 17-38). Aldershot: Ashgate.

Rystad, G. (1992). Immigration history and the future of international migration. International Migration Review, 26, bls. 1168-1199.

Unnur Dís Skaptadóttir (2004). Fjölmenning á ferð og flugi. Í Úlfar Hauksson (ritstjóri), Rannsóknir i félagsvísindum V: Félagsvísindadeild (bls. 585-591). Reykjavík: Háskólaútgáfan.

van Oorschot, W. og Uunk, W. (2007). Multi-level determinants of the public's informal solidarity towards immigrants in European welfare states. Í Mau, S. og Veghte, B. (ritstjórar), Social justice, legitimacy and the welfare state (bls. 217-238). Aldershot: Ashgate. 
Vinnumálastofnun (2007). Erlent starfsfólk á íslenskum vinnumarkaði. Greinargerð á vefsíðu

Vinnumálastofnunar, dagsett 19. október 2007. Slóð:

http://www.vinnumalastofnun.is/files/Erlent\%20starfsf\%C3\%B3lk

\%20\%C3\%A1\%20\%C3\%ADslenskum\%20vinnumarka\%C3\%B0i\%20haust

\%202007_1728410651.pdf.

World Value Survey (e.d.). Gögn sótt 12. nóvember 2009 af www.worldvaluessurvey.org.

\section{Viðauki}

Menntun, kyn, aldur, búseta, og starf svarenda og afstaða peirra til pess hvort pað skipti miklu eða litlu máli að bæta lífskjör útlendinga á Íslandi.

\begin{tabular}{|c|c|c|c|}
\hline & Fjöldi & Hlutfall svara & $\begin{array}{c}\text { Meðaltal } \\
\text { (staðalfrávik) }\end{array}$ \\
\hline \multicolumn{4}{|l|}{ Menntun } \\
\hline Grunnskólapróf & 136 & $25,1 \%$ & \\
\hline Menntun á framhaldsskólastigi & 133 & $24,6 \%$ & \\
\hline Iðnmenntun & 94 & $17,4 \%$ & \\
\hline Háskólamenntun & 178 & $32,9 \%$ & \\
\hline \multicolumn{4}{|l|}{ Kyn } \\
\hline Karl & 282 & $50,2 \%$ & \\
\hline Kona & 280 & $49,8 \%$ & \\
\hline Aldur & & & $\begin{array}{c}45 \\
(15,72)\end{array}$ \\
\hline \multicolumn{4}{|l|}{ Búseta } \\
\hline Höfuðborgarsvæði & 343 & $61,0 \%$ & \\
\hline Utan höfuðborgarsvæðis & 219 & $39,0 \%$ & \\
\hline \multicolumn{4}{|l|}{ Starf svarenda } \\
\hline $\begin{array}{l}\text { Kjörnir fulltrúar, æðstu embættismenn, } \\
\text { sérfræðingar, tæknar og sérmenntað starfsfólk }\end{array}$ & 173 & $36,4 \%$ & \\
\hline Skrifstofufólk, pjónustu,- sölu- og afgreiðslufólk & 154 & $32,4 \%$ & \\
\hline $\begin{array}{l}\text { Bændur, sjómenn, iðnaðarmenn, véla- og } \\
\text { vélgæslufólk }\end{array}$ & 105 & $22,1 \%$ & \\
\hline Ósérhæft starfsfólk & 43 & $9,1 \%$ & \\
\hline \multicolumn{4}{|l|}{ Finnst pér skipta miklu eða litlu máli að bæta } \\
\hline \multicolumn{4}{|l|}{ lífskjör útlendinga á Íslandi? } \\
\hline Skiptir mjög litlu máli & 53 & $10,2 \%$ & \\
\hline Skiptir frekar litlu máli & 62 & $11,9 \%$ & \\
\hline Skiptir hvorki litlu né miklu máli & 70 & $13,4 \%$ & \\
\hline Skiptir frekar miklu máli & 178 & $34,2 \%$ & \\
\hline Skiptir mjög miklu máli & 158 & $30,3 \%$ & \\
\hline
\end{tabular}

